\title{
Paleoenvironmental reconstruction of the coastal Monte Léon and Santa Cruz formations (Early Miocene) at Rincón del Buque, Southern Patagonia: A revisited locality
}

\author{
M. Sol Raigemborn a, b, *, Sergio D. Matheos a, Verónica Krapovickas c , Sergio F. Vizcaíno d, \\ M. Susana Bargo ${ }^{\mathrm{e}}$, Richard F. Kay ${ }^{\mathrm{f}}$, Juan C. Fernicola ${ }^{\mathrm{g}}$, h, Luciano Zapata ${ }^{\mathrm{a}}$ \\ ${ }^{a}$ CONICET - UNLP, Centro de Investigaciones Geológicas, Calle 1 644, 1900 La Plata, Argentina \\ b Cátedra de Fundamentos de Geología, Facultad de Ciencias Naturales y Museo, Calle 122 y 60 s/n, 1900 La Plata, Argentina \\ c IDEAN-CONICET, Departamento de Ciencias Geológicas, FCEyN, UBA, Ciudad Universitaria, Pabellón 2, C1428EHA Buenos Aires, Argentina \\ d División Paleontología de Vertebrados (CONICET), Museo de La Plata (UNLP), Paseo del Bosque s/n, 1900 La Plata, Argentina \\ e División Paleontología de Vertebrados (CIC), Museo de La Plata (UNLP), Paseo del Bosque s/n, 1900 La Plata, Argentina \\ ${ }^{\mathrm{f}}$ Department of Biological Anthropology and Anatomy, Duke University, Box 90383, Durham, NC 27708, USA \\ g CONICET-Sección Paleontología de Vertebrados, Museo Argentino de Ciencias Naturales, “Bernardino Rivadavia”, Av. Ángel Gallardo 470, Ciudad \\ Autónoma de Buenos Aires, Argentina \\ ${ }^{\mathrm{h}}$ Departamento de Ciencias Básicas, Universidad Nacional de Luján Ruta 5 y Avenida Constitución, 6700 Luján, Buenos Aires, Argentina
}

\section{A R T I C L E I N F O}

\section{Article history:}

Received 15 August 2014

Accepted 2 March 2015

Available online 11 March 2015

\section{Keywords:}

Estuarine and fluvial systems

Volcanic input

Ichnology

Fossil mammals

Neogene

Santa Cruz Province

\begin{abstract}
A B S T R A C T
Sedimentological, ichnological and paleontological analyses of the Early Miocene uppermost Monte León Formation and the lower part of the Santa Cruz Formation were carried out in Rincón del Buque (RDB), a fossiliferous locality north of Río Coyle in Santa Cruz Province, Patagonia, Argentina. This locality is of special importance because it contains the basal contact between the Monte Léon (MLF) and the Santa Cruz (SCF) formations and because it preserves a rich fossil assemblage of marine invertebrates and marine trace fossils, and terrestrial vertebrates and plants, which has not been extensively studied. A 90 m-thick section of the MLF and the SCF that crops out at RDB was selected for this study. Eleven facies associations (FA) are described, which are, from base to top: subtidal-intertidal deposits with Crassotrea orbignyi and bioturbation of the Skolithos-Cruziana ichnofacies (FA1); tidal creek deposits with terrestrial fossil mammals and Ophiomorpha isp. burrows (FA2); tidal flat deposits with Glossifungites ichnofacies (FA3); deposits of tidal channels (FA4) and tidal sand flats (FA5) both with and impoverish Skolithos ichnofacies associated; marsh deposits (FA6); tidal point bar deposits recording a depauperate mixture of both the Skolithos and Cruziana ichnofacies (FA7); fluvial channel deposits (FA8); fluvial point bar deposits (FA9); floodplain deposits (FA10); and pyroclastic and volcaniclastic deposits of the floodplain where terrestrial fossil mammal remains occur (FA11).

The transition of the MLF-SCF at RDB reflects a changing depositional environment from the outer part of an estuary (FA1) through the central (FA2-6) to inner part of a tide-dominated estuary (FA7). Finally a fluvial system occurs with single channels of relatively low energy and low sinuosity enclosed by a broad, low-energy floodplain dominated by partially edaphized ash-fall, sheet-flood, and overbank deposits (FA8-11). Pyroclastic and volcaniclastic materials throughout the succession must have been deposited as ash-fall distal facies in a fluvial setting and also were carried by fluvial streams and redeposited in both estuarine and fluvial settings. These materials preserve most of the analyzed terrestrial fossil mammals that characterize the Santacrucian age of the RDB's succession. Episodic sedimentation
\end{abstract}

\footnotetext{
* Corresponding author. CONICET - UNLP, Centro de Investigaciones Geológicas, Calle 1 644, 1900 La Plata, Argentina. Tel.: +54 221421 5677; fax: +54 221482 7560 .

E-mail addresses: msol@cig.museo.unlp.edu.ar (M.S. Raigemborn),smatheos@ cig.museo.unlp.edu.ar (S.D. Matheos), veronicakrapovickas@gmail.com (V. Krapovickas), vizcaino@fcnym.unlp.edu.ar (S.F. Vizcaíno), msbargo@fcnym. unlp.edu.ar (M.S. Bargo), richard.kay@duke.edu (R.F. Kay), jctano@yahoo.com (J.C. Fernicola), lucianozapata@gmail.com (L. Zapata).
} 
under volcanic influence, high sedimentation rates and a relatively warm and seasonal climate are inferred for the MLF and SCF section.

Lateral continuity of the marker horizons at RDB serve for correlation with other coastal localities such as the lower part of the coastal SCF south of Río Coyle ( 17.6-17.4 Ma) belonging to the Estancia La Costa Member of the SCF.

() 2015 Elsevier Ltd. All rights reserved.

\section{Introduction}

Early Miocene deposits of the Santa Cruz Formation (SCF), widely distributed in the Austral or Magallanes basin (Patagonia, Argentina) (Fig. 1A), contain a rich assemblage of fossil mammals, studied since the 19th Century (Vizcaino et al., 2012a, and references therein). The best-known fossiliferous exposures of the SCF crop out along the Atlantic coastline of the Santa Cruz Province between Río Santa Cruz and Río Gallegos (Vizcaíno et al., 2012a, Fig. 1A) (Fig. 1B). The fossil content of these localities was placed in a stratigraphic sedimentological context by Tauber (1994; 1997a; 1997b). Since then, abundant new data on the sedimentology (Matheos et al., 2008, 2010; Matheos and Raigemborn, 2012; Raigemborn et al., 2012), geochronology (Fleagle et al., 2012; Perkins et al., 2012), ichnology (Krapovickas, 2012; Krapovickas et al., 2013; Zapata et al., 2013), paleosols (Raigemborn et al., 2012) and paleobotany (Brea et al., 2012) contributed to a revised understanding of the temporal succession and paleoenvironments of coastal exposure of the SCF between Río Coyle and Río Gallegos (Vizcaíno et al., 2012a).

Localities north to Río Coyle (Fig. 1A) have received less attention, although there are geological and paleontological studies for Cerro Observatorio at Cañadón de las Vacas (Bown and Fleagle, 1993) (referred to as Monte Observación by these authors), and Monte León and Monte Observación in the Monte León National Park (Bown and Fleagle, 1993; Matheos et al., 2008). A third largely undocumented area is Rincón del Buque (RDB), named as Media Luna, Wreck Flat or Smith's Rock Flat by Bordas (1941), Feruglio (1949), Marshall (1976), Marshall et al. (1986) and Vizcaíno et al. (2012b) (Fig. 1C). Literature about the geology and paleontology of RDB is scarce. Ameghino (1906) does not mention it but provides sections of outcrops of his Superpatagoniense (upper MLF) and Santacrucense (SCF) between Río Santa Cruz and Río Coyle that would have included the area. Describing the Santacrucense between Río Santa Cruz and Río Coyle, Feruglio (1949) mentioned that at RDB the Santacrucense is 250 m-thick with layers disposed practically horizontally, that it is composed of interbedded fine tuffaceous material and pebbly sandstones, and that an oyster bed and several levels of white tuff can be used as local guide layers. Marshall et al. (1986) described RDB as a large amphitheater opening towards the sea (Fig. 1C) and located about $23 \mathrm{~km}$ north of Coy Inlet; this amphitheater is depicted as about $4 \mathrm{~km}$ in $\mathrm{N}-\mathrm{S} \mathrm{di-}$ rection, and labeled Media Luna on recent maps (Marshall, 1976; Vizcaíno et al., 2012b). Marshall et al. (1986) dated a rock sample using the potassium-argon method from the NE side of the amphitheater about $20 \mathrm{~m}$ above the exposed base of the outcrops, obtaining an age of $\sim 16 \mathrm{Ma}$. The Riggs Expedition from the Field Museum of Natural History of Chicago (USA) made a collection of fossil mammals from RDB in 1923. They referred to the area as Wreck Flat or Smith's Rock Flat (Marshall, 1976; Vizcaíno et al., 2012b). Rigg's expedition collected 282 specimens belonging to 32 mammals species and a few birds (according to field identifications; Riggs, 1928). Later, José Brandmayr, from the argentine national oil company YPF, collected 23 fossils from a white tuff $35 \mathrm{~m}$ above the upper oyster bed of the Superpatagoniense that were briefly described by Bordas (1941). Consequently, from a stratigraphic point of view, RDB locality is highly interesting because it contains the contact between the Monte Léon and the Santa Cruz formations. It is also rich in fossil vertebrates and trace fossils that together with a precise sedimentological analysis, allowed us to interpret the environmental conditions at the time of deposition.

The goals of this paper are 1) to provide a detailed stratigraphic, sedimentological and ichnological description of RDB; 2) to interpret depositional paleoenvironments of the uppermost MLF and the lower part of the SCF in this area, 3) to provide a preliminary list of the fossil mammals identified so far; 4) to integrate the former information to infer paleoenvironmental conditions of this locality, considering the effects of the volcanism on the sedimentary environments, and including a paleoclimatic reconstruction, and 5) discuss probable correlations with other known fossiliferous localities.

\section{Geological setting and study area}

\subsection{Tectonic framework}

The Austral basin is located in southernmost South America (Russo et al., 1980; Biddle et al., 1986; Olivero and Malumián, 2002 2008; Menichetti et al., 2008). It follows mainly a NNW-SSE axis limited by the Southern Patagonian Andes mountain range towards the west, and by the Río Chico High to the east (Biddle et al., 1986; Corbella, 2002; Peroni et al., 2002) (Fig. 1A). The latter represents a southern extension of the Deseado Massif that served as the basement for the Cretaceous/Cenozoic sedimentation, separating the Austral basin from the Malvinas basin (Rossello et al., 2008).

The geological history of the Austral basin begins in the Triassic with the initiation of rifting between South America and Africa (Biddle et al., 1986). During the Late Jurassic-Early Cretaceous, the margin of the basin was formed by the uplift of the western arc (Arbe, 1987; Corbella, 2002). From the Early Cretaceous to the Miocene, the basin experienced episodes of marine and continental deposition accompanied by repeated transgressions and regressions. From the Late Oligocene to the Early Miocene, a widespread transgression occurred in Patagonian basins, covering most of southern Patagonia (Malumián, 1999). This transgression and the deposition of the overlaying continental series are the result of several factors including: 1) Miocene deformation and uplift of the cordillera in the west (Guillaume et al., 2009; Ramos and Ghiglione, 2008), 2) important climate changes related to an increase in the global temperature (Zachos et al., 2008) and 3) worldwide fluctuations in sea-level (Miller et al., 2005).

\subsection{Sedimentological and paleontological framework}

The pre-Cenozoic infill of the Austral basin contains deep marine to continental sedimentary units and volcaniclastic deposits of Late Jurassic to Late Cretaceous age as Complejo El Quemado, Springhill, Río Mayer, Kachaike, Piedra Clavada, Mata Amarilla, Alta Vista, Asunción, Cerro Fortaleza and Calafate formations and their equivalents (e.g. Sacomani and Panza, 2012). The 


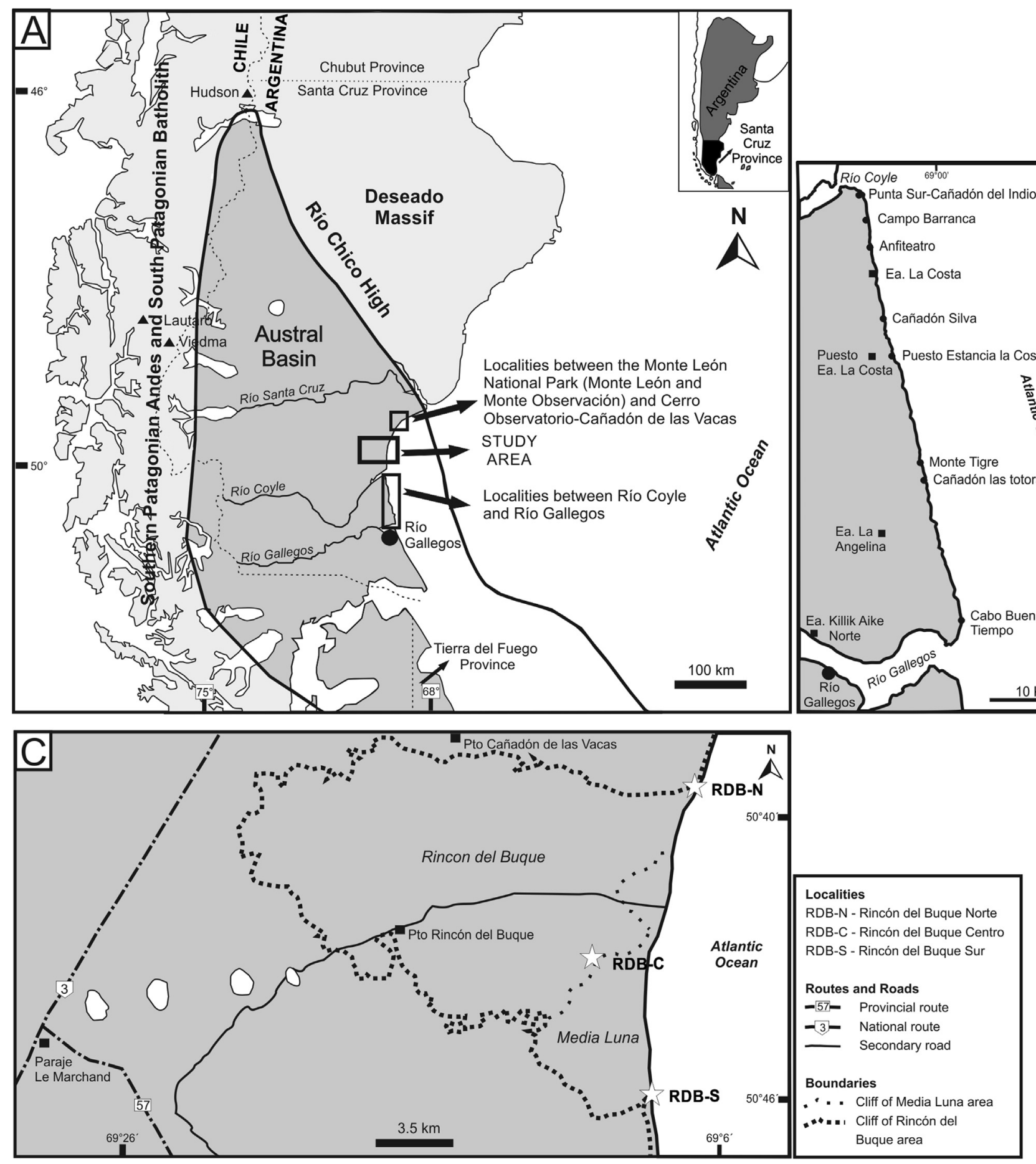

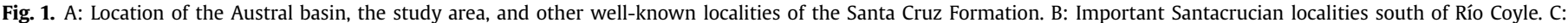
Simplified map of the Rincón del Buque area showing the position of the three analyzed sections.

Paleogene-Neogene infill of the basin is composed of marine units deposited during Atlantic transgressions intercalated with intervals of non-deposition, erosion and continental deposition (Malumián, 1999). The Patagoniense transgression occurred in three episodes named by Ameghino (1902) as Juliense, Leonense and Superpatagónico, the last of which is overlain by his Formación Santacruceña. The "Juliense" and "Leonense" are well exposed on the coastal parts of the Austral basin and were formally named as San Julián and Monte León formations, respectively (Bertels, 1970).
In this area the San Julián Formation onlaps felsic volcanic and siliciclastic rocks of the Jurassic Bahía Laura Group (Parras et al., 2012). The marine "Superpatagónico" stage, considered to be part of the upper MLF in the study area, is conformably overlain by the continental Formación Santacruceña of Ameghino (1902), now called the Santa Cruz Formation (see a review in Parras and Griffin, 2009; Griffin and Parras, 2012). Unconformably beneath the Monte León Formation lies the marine San Julián Formation (Parras et al., 2008). The MLF includes siltstones, mudstones, tuffs and 
intercalated shell beds (Bertels, 1970), with frequent bioturbation, deposited in shallow seas, ranging from coastal plain (subtidal or intertidal environments) to shallow continental shelf systems (Parras and Griffin, 2009; Griffin and Parras, 2012). Bown and Fleagle (1993) mentioned that the uppermost $15 \mathrm{~m}$ of the MLF contains fluvial levels with paleosols, as well as thin intercalations of marine sediments with the oyster Ostrea hatcheri. On the basis of the invertebrates, palynomorphs (Barreda and Palamarczuk, 2000), and ${ }^{87} \mathrm{Sr} /{ }^{86} \mathrm{Sr}$ ages, the San Julián and the Monte León formations spanning the interval of $\sim 25$ to $\sim 18 \mathrm{Ma}$ (Late Oligocene-Early Miocene) (Parras et al., 2012).

In the coastal area of the basin, the marine MLF is succeeded transitionally by continental deposits of the SCF (Feruglio, 1949; Tauber, 1994; Barreda and Palamarczuk, 2000; Matheos et al., 2008; Matheos and Raigemborn, 2012) (Fig. 2). For the coastal zone the SCF is roughly $225 \mathrm{~m}$ thick mainly composed of mudstones, fine to medium sandstones of volcaniclastic origin, and tuffs with light colors, containing immature paleosols and laid down on a coastal plain incised by sand bodies representing river channels (Bown and Fleagle, 1993; Tauber, 1994, 1997a). In the coastal outcrops of the SCF south of Río Coyle (Fig. 1B), Tauber (1994, 1997a; 1997b) recognized two members separated by a locally erosional discontinuity: a lower unit, the Estancia La Costa Member, with a predominance of claystones and mudstones of pyroclastic origin; and an upper unit, the Estancia La Angelina Member, chiefly composed of pyroclastic claystones, mudstones, and sandstones

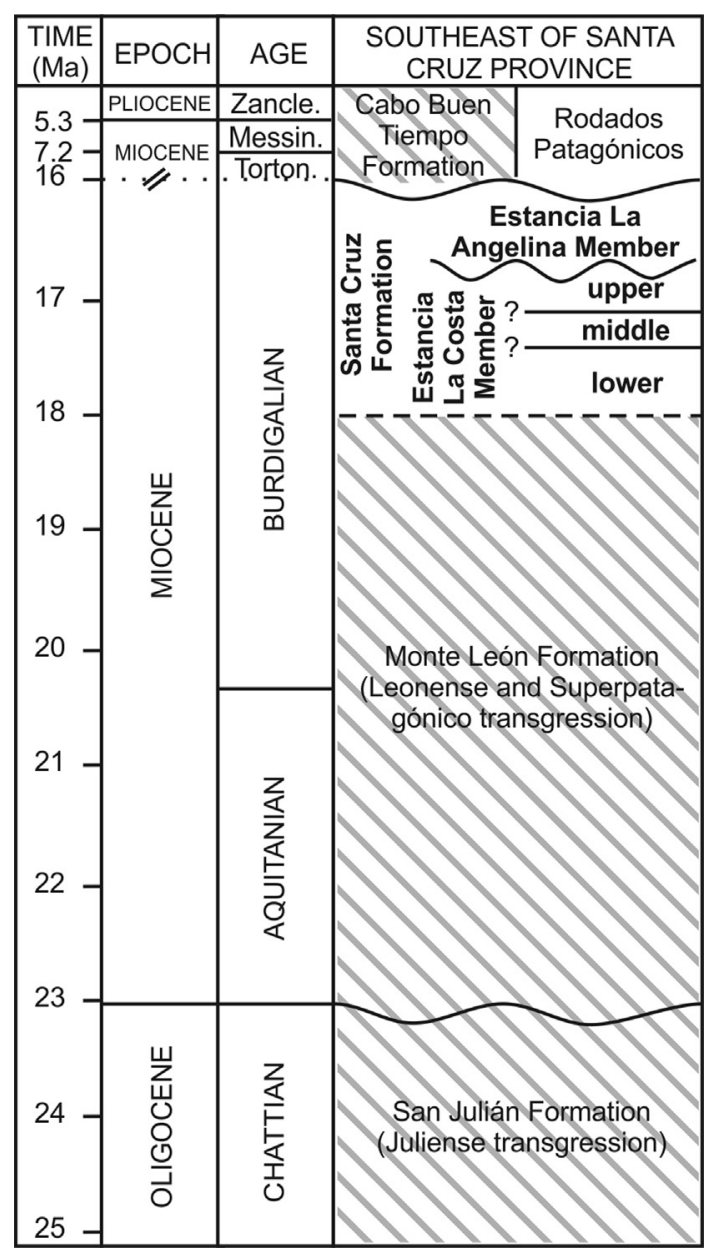

Fig. 2. Stratigraphic chart of the southeast Santa Cruz Province with timescale of Gradstein et al. (2012). The oblique stripes indicate marine deposits.
(Fig. 2). Recently, compositional and sedimentological analyses of the Estancia La Costa Member of the SCF south of Río Coyle, allowed Matheos and Raigemborn (2012) to differentiate three parts: lower, middle and upper. Throughout these three parts there is a decrease in pyroclastic materials (primary and reworked tuffs) and an increase in the participation of coarse facies and paleosols, which were interpreted as indicating an increase in the energy of the fluvial system.

Mammal faunas from the richly fossiliferous SCF were the basis for recognition of the Santacrucian Land Mammal Age of South America (Pascual et al., 1965). The Santacrucian is one of the most diverse taxonomically and better represented in terms of the preservation of specimens of all Cenozoic mammal faunas in South America before the Plio-Pleistocene closure of the Panamian isthmus (Marshall et al., 1986).

The absolute age of the SCF has been a subject of debate for more than a century (e.g. Marshall et al., 1986; Bown and Fleagle, 1993; Fleagle et al., 1995; Blisniuk et al., 2005). Recent radiometric dates of intercalated tuffs levels (Perkins et al., 2012; Fleagle et al., 2012) indicate that the coastal SCF spans the interval $~ 17.9-16.2$ and a greater temporal interval, 19-14 Ma, in the Andean foothills. During the period of deposition of the lower part of the SCF climate conditions in the south coastal Atlantic were extratropical and highly seasonal (see a review in Kay et al., 2012; Palazezzi et al., 2014).

Deposits of the SCF in the south Atlantic area are overlying disconformably by Late Miocene-Pleistocene marine and glaciofluvial sediments, the Cape Fairweather beds of Hatcher (Cabo Buen Tiempo Formation) and the "Rodados Patagónicos" (Fig. 2).

\subsection{The study area}

The RDB area is located in the northeastern boundary of the Austral basin (southeast coast of the Santa Cruz Province), between Río Santa Cruz and Río Coyle (Fig. 1A). The area is within the boundaries of the Estancia Coy Inlet, Estancia Cañadón de las Vacas, and Estancia Ototel Aike. The exposures extend between $50^{\circ} 39^{\prime} 30^{\prime \prime}$ and $50^{\circ} 46^{\prime} 10^{\prime \prime} \mathrm{S}$, and stretch as far west as $69^{\circ} 10^{\prime} 14^{\prime \prime} \mathrm{W}$ from the Atlantic coast (Fig. 1C).

In the study area the outcrops of the uppermost MLF and of the lower part of the SCF are arrayed parallel to the Atlantic coastline, in active cliffs along the coast and nearby inland hills (Fig. 3). The transition between the MLF and the SCF appears conformable and gradual. The boundary between both units is placed subjectively in the top of the last oyster bed, similar to the criteria followed by Cuitiño et al. (2012). The contact between the two formations is exposed in the intertidal zone where the last oyster layer of the MLF with specimens in life position of Crassostrea orbignyi (Ihering, 1897) and other reworked marine mollusks (Griffin and Parras, 2012) take place (Fig. 3A). In this area the SCF is capped by the Pleistocene glacio-fluvial conglomerate of the Rodados Patagónicos (Fig. 2).

\section{Material and methods}

Three sedimentary sections exposed in the study area were measured. From north to south these are: Rincón del Buque Norte (RDB-N) $\left(50^{\circ} 39^{\prime} 30^{\prime \prime} \mathrm{S} ; 6^{\circ} 06^{\prime} 38^{\prime \prime} \mathrm{W}\right)$, Rincón del Buque Centro (RDB-C) $\left(50^{\circ} 43^{\prime} 21^{\prime \prime} \mathrm{S} ; 69^{\circ} 10^{\prime} 14^{\prime \prime} \mathrm{W}\right)$ and Rincón del Buque Sur (RDBS) $\left(50^{\circ} 46^{\prime} 10^{\prime \prime} \mathrm{S} ; 69^{\circ} 08^{\prime} 17^{\prime \prime} \mathrm{W}\right)$ (Fig. 1C).

Facies and facies associations were described, following Miall (1996) and Bridge (2003) with modification for pyroclastic deposits (Smith, 1987). In the field, paleosols and rock colors were determined using the Geological Rock-color Chart (2009). The external shape of the sand bodies were described following the 

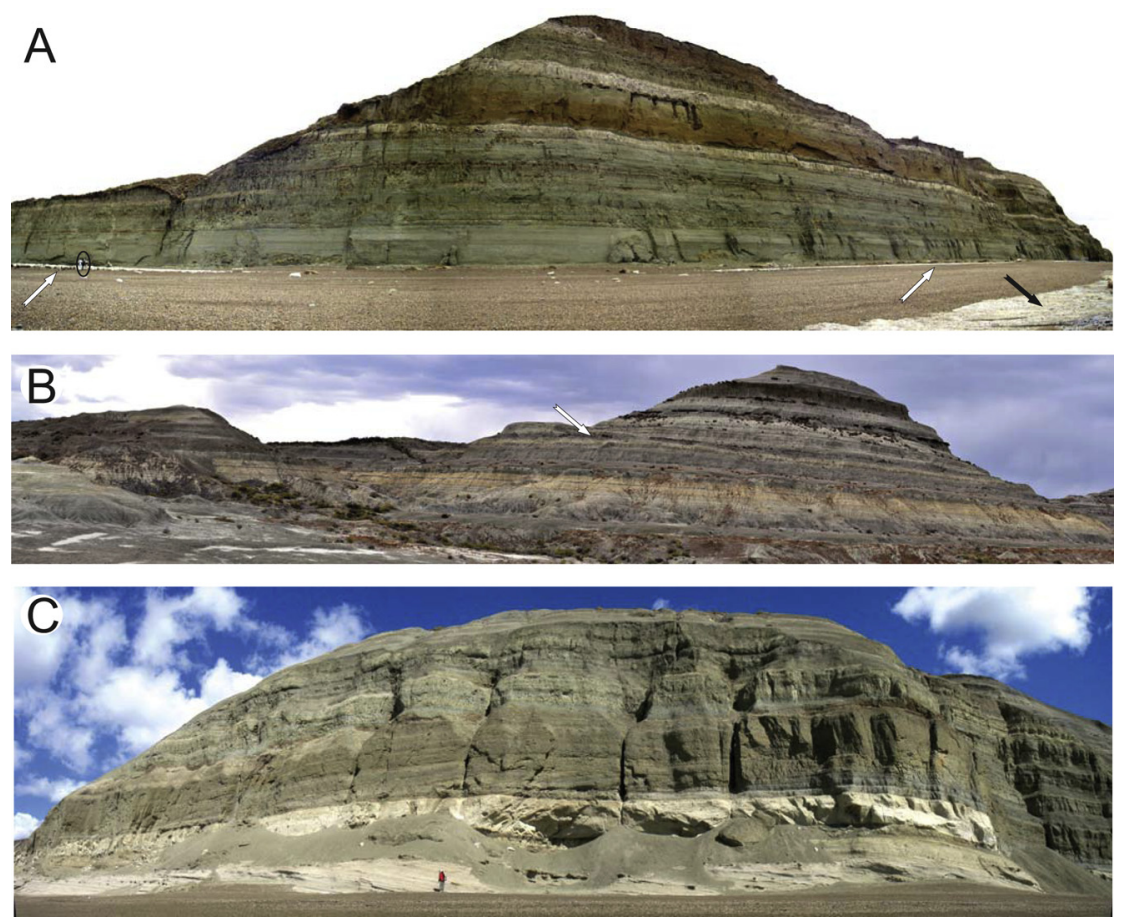

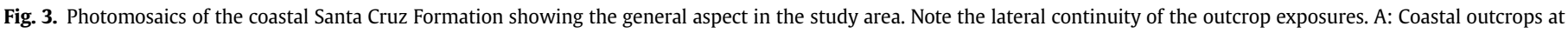

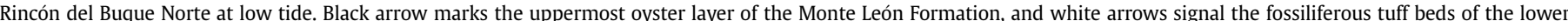

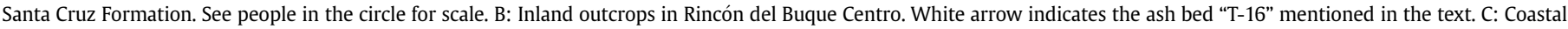
outcrops in Rincón del Buque Sur illustrating the lowermost part of the Santa Cruz Formation.

width/thickness (W/Th) criteria of Gibling (2006) as broad sheets $(\mathrm{W} / \mathrm{Th}>100)$, narrow sheets $(\mathrm{W} / \mathrm{Th}>15)$, broad ribbons $(\mathrm{W} / \mathrm{Th}>5)$ and narrow ribbons $(\mathrm{W} / \mathrm{Th}<5)$.

Trace fossils were studied and photographed in situ and left in the field. We use the preservational nomenclature of Seilacher (1964) and the Bioturbation Index (BI) of Droser and Bottjer (1986).

Preliminary collections of fossil vertebrates (birds and mammals) were made by some of the authors (SFV, MSB, RFK and JCF). The specimens are preserved and cataloged into the permanent collections to the Museo Regional Provincial Padre M.J. Molina of the Río Gallegos city (Santa Cruz Province). The coordinates of the fossils were recorded. Fossils were collected mainly from areas adjacent to where the sedimentary sections were measured. A record was made of whether the fossils were in situ or in lag deposits and they were referred to stratigraphic position relative to a marker horizon named arbitrary as "T-16", which is described below. This horizon is considered a local guide bed due to the fact that it is a fossil-rich pyroclastic level with a kilometer lateral continuity that takes place in the three measured sections at RDB.

\section{Results}

\subsection{Sedimentology, trace-fossil distribution, and depositional environments}

For this study we selected a $\sim 90$ m-thick section of the uppermost MLF and the lower part of the SCF that crops out in the analyzed area. It is composed of bioclastic, pyroclastic (tuffs), volcaniclastic (reworked tuffs and tuffaceous sandstones) and epiclastic (siltstones, sandstones and sporadic pebbly sandstones) deposits (Fig. 4). Sixteen sedimentary facies were defined on the basis of lithology, sedimentary structures, fossil content and trace fossils, and paleoedaphic features (Table 1). The succession starts with volcaniclastic facies (Tw) that are overlaid by bioclastic facies (Sb) of the MLF. The last are covered by volcaniclastic (Tw, TS) and epiclastic facies (St, Sp, Sh, Sr, Sm, HS, IHS, Fm) (Table 1) of the SCF which arrange in a finning-upward succession grayish olive to light gray in color of $~ 10-20 \mathrm{~m}$-thick. These facies arrange in seven facies associations (FA) (Table 2) which are: subtidal-intertidal deposits (FA1); tidal creek deposits (FA2); tidal flat deposits (FA3); tidal channel deposits (FA4); tidal sand flat deposits (FA5); marsh deposits (FA6); and tidal point bar deposits (FA7). Upward this succession is covered by fluvial deposits composed of epiclastic $(\mathrm{Gm}$, Gt, St, Sp, Sm, Sl, Fm, Fl), pyroclastic (T) and volcaniclastic (Tw) facies (Figs. 3 and 4, Table 1) of four FA (Table 2) which are: fluvial channel deposits (FA8); fluvial point bar deposits (FA9); floodplain deposits (FA10); and pyroclastic and volcaniclastic deposits of the floodplain (FA11). Six trace fossil assemblages (TFA) related with the FA are shown in Table 3. Fluvial deposits of the SCF arrange in a $\sim 18$ to 34 m-thick succession, present in the three measured sections. Epiclastic facies are divided into fine- and coarse-grained. Bodies of fine-grained facies (Sm, Sl, Fm, Fl) are vertically stacked up to $30 \mathrm{~m}$, and pyroclastic and volcaniclastic deposits ( $\mathrm{T}$ and $\mathrm{Tw}$ ) are interbedded within this stacking. Coarse-grained facies (Gm, Gt, $\mathrm{St}, \mathrm{Sp}$ ) are uncommon in the fluvial deposits in RDB, and they occur exclusively at middle-upper part of the analyzed succession (Fig. 4).

\subsubsection{Facies association 1: subtidal-intertidal deposits}

Description: FA1 of the uppermost MLF is composed of marine bioturbated Tw facies (Fig. 4) and broad massive bodies of Sb facies bearing oysters $-C$. orbignyi (Ihering, 1897) - in life position and a smaller number of reworked marine mollusks described by Griffin and Parras (2012) (Figs. 3A, 4 and 5D). Deposits of Tw facies crop out without an exposed base with irregular $0.5 \mathrm{~m}$-thick top surfaces, which are covered by deposits of Sb facies. The latter presents 


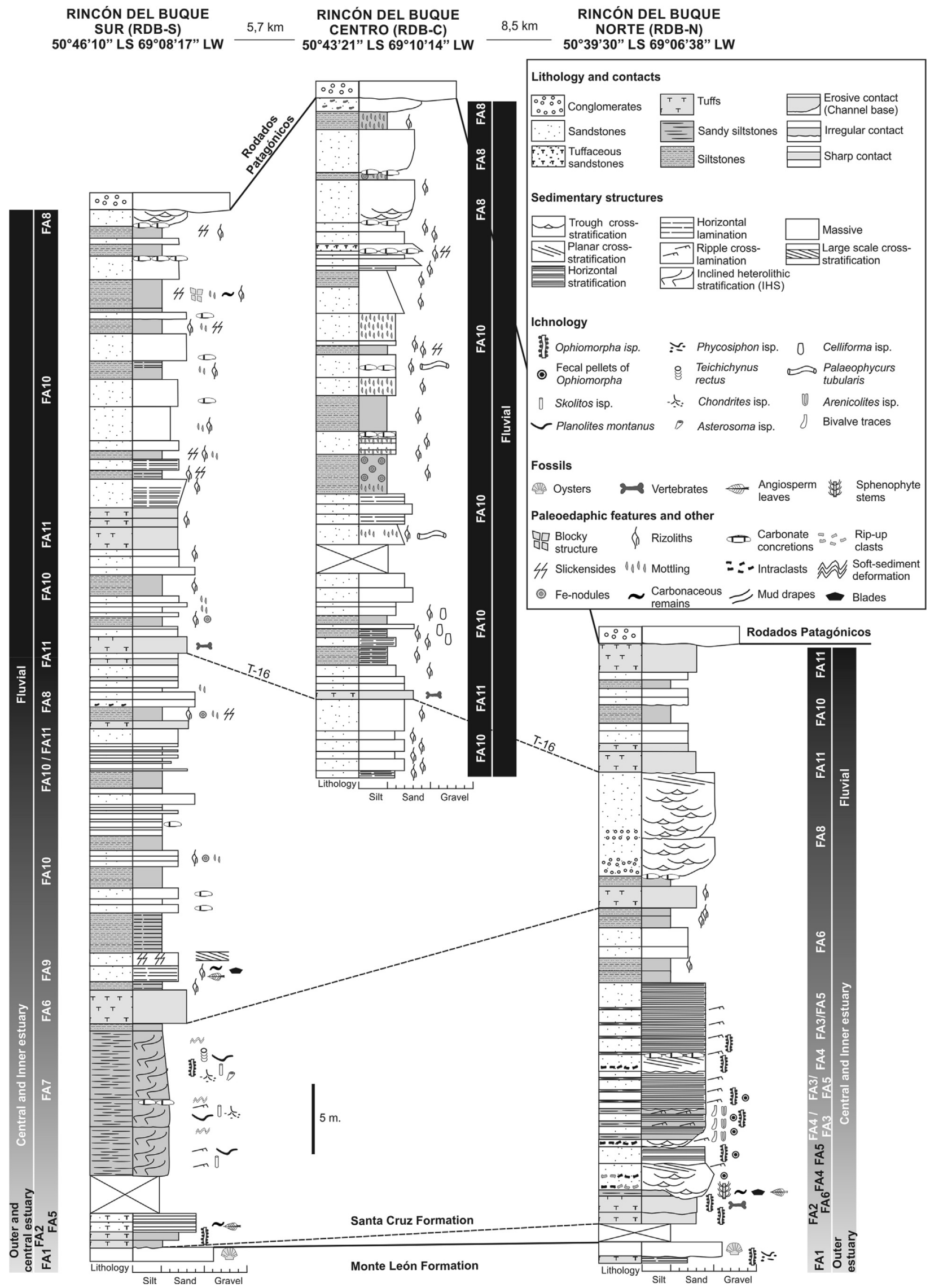

Fig. 4. Detailed sedimentary sections of the Rincón del Buque area. 
Table 1

Description and interpretation of the sedimentary facies.

\begin{tabular}{|c|c|c|c|c|c|}
\hline $\begin{array}{l}\text { Facies } \\
\text { code }\end{array}$ & Lithology & Sedimetary structures & Fossil content & Other features & Interpretation \\
\hline $\mathrm{Sb}$ & $\begin{array}{l}\text { Very fine bioclastic tuffaceous } \\
\text { sandstones }\end{array}$ & Massive & $\begin{array}{l}\text { Oysters (Crassostrea orbigny) } \\
\text { and other marine mollusks }\end{array}$ & - & $\begin{array}{l}\text { Oyster bioherms or reefs with } \\
\text { oysters and in place reworked and } \\
\text { redeposited mollusks in tide- } \\
\text { influenced settings }\end{array}$ \\
\hline Tw & $\begin{array}{l}\text { Very fine- to medium-grained } \\
\text { reworked tuffs }\end{array}$ & Massive or laminated & $\begin{array}{l}\text { Ophiomorpha isp., c.f. } \\
\text { Phycosiphon, } \\
\text { Skolithos isp., Palaeophycus } \\
\text { tubularis. } \\
\text { Terrestrial mammals }\end{array}$ & Sporadic rhizoliths & $\begin{array}{l}\text { Reworked ash-fall materials mixed } \\
\text { with other sediments and } \\
\text { deposited in tide-influenced } \\
\text { settings with subsequent marine } \\
\text { bioturbation, and in fluvial settings } \\
\text { with sub-aereal exposure and } \\
\text { pedogenetic modification }\end{array}$ \\
\hline TS & $\begin{array}{l}\text { Medium- to coarse-grained } \\
\text { tuffaceous sandstones }\end{array}$ & Horizontal stratification & Leaves of Nothofagaceae & Carbonaceous remains & $\begin{array}{l}\text { Reworking of pyroclastic material } \\
\text { mixed with epiclastic materials } \\
\text { with developed of upper-stage } \\
\text { plane beds in tide-influenced } \\
\text { settings }\end{array}$ \\
\hline $\mathrm{T}$ & $\begin{array}{l}\text { Fine- to medium-grained } \\
\text { primary tuffs }\end{array}$ & Massive & Terrestrial mammals & - & $\begin{array}{l}\text { Deposition of ash-fall in sub-aerial } \\
\text { and subaqueous fluvial settings }\end{array}$ \\
\hline $\mathrm{Gm}$ & Fine-grained conglomerates & Massive & - & - & Fluvial channel lag deposits \\
\hline $\mathrm{Gt}$ & Fine-grained conglomerates & Trough-cross stratification & - & - & $\begin{array}{l}\text { Migration of gravely 3-dimensional } \\
\text { dunes in fluvial channels and bars }\end{array}$ \\
\hline St & $\begin{array}{l}\text { Medium- to very coarse- } \\
\text { grained or pebbly sandstones }\end{array}$ & Trough-cross stratification & Ophiomorpha isp., fecal pellets & $\begin{array}{l}\text { Mud drapes, muddy rip-up } \\
\text { clasts }\end{array}$ & $\begin{array}{l}\text { Migration of sandy 3-dimensional } \\
\text { dunes in tidal settings with } \\
\text { subsequent marine bioturbation, } \\
\text { and in fluvial deposits }\end{array}$ \\
\hline $\mathrm{Sp}$ & $\begin{array}{l}\text { Medium- to coarse-grained } \\
\text { sandstones }\end{array}$ & Planar-cross stratification & Ophiomorpha isp., fecal pellets & $\begin{array}{l}\text { Mud drapes, muddy rip-up } \\
\text { clasts }\end{array}$ & $\begin{array}{l}\text { Migration of sandy 2-dimensional } \\
\text { dunes in tidal settings with } \\
\text { subsequent marine bioturbation, } \\
\text { and in fluvial deposits }\end{array}$ \\
\hline Sh & $\begin{array}{l}\text { Medium- to coarse-grained } \\
\text { sandstones }\end{array}$ & Horizontal stratification & Ophiomorpha isp., fecal pellets & Mud clasts, mud drapes & $\begin{array}{l}\text { Upper-flow regime plane beds in } \\
\text { tide-influenced settings with } \\
\text { subsequent marine bioturbation }\end{array}$ \\
\hline $\mathrm{Sl}$ & $\begin{array}{l}\text { Very fine- to medium-grained } \\
\text { sandstones }\end{array}$ & $\begin{array}{l}\text { Horizontal lamination. Large } \\
\text { scale- cross stratification }\end{array}$ & $\begin{array}{l}\text { Leaves of angiosperms. } \\
\text { Celliforma isp. }\end{array}$ & $\begin{array}{l}\text { Carbonaceous remains, blades, } \\
\text { slickensides, Rhizoliths, } \\
\text { mottling }\end{array}$ & $\begin{array}{l}\text { Upper stage plane-bed flow in } \\
\text { fluvial settings. Sporadic sub-aereal } \\
\text { exposure with incipient pedogenic } \\
\text { modification and terrestrial } \\
\text { bioturbation. Lateral accretion } \\
\text { deposits }\end{array}$ \\
\hline $\mathrm{Sr}$ & Fine-grained sandstones & Ripple-cross lamination & Arenicolites isp. & Mud drapes & $\begin{array}{l}\text { Migration of ripples in tide- } \\
\text { influenced settings with } \\
\text { subsequent marine bioturbation }\end{array}$ \\
\hline Sm & $\begin{array}{l}\text { Very fine- to medium-grained } \\
\text { sandstones }\end{array}$ & Massive & $\begin{array}{l}\text { Angiosperm leaves. Arenicolites } \\
\text { isp. } \\
\text { Palaeophycus tubularis }\end{array}$ & $\begin{array}{l}\text { Rhizoliths, mottling, Fe- } \\
\text { nodules, slickensides, } \\
\text { carbonaceous remains, } \\
\text { calcareous concretions. } \\
\text { Sporadic blocky structure }\end{array}$ & $\begin{array}{l}\text { Stream-flow during high discharge } \\
\text { conditions in tide-influenced } \\
\text { settings with subsequent marine } \\
\text { bioturbation, and in fluvial settings } \\
\text { with sub-aereal exposure, } \\
\text { pedogenic modification and } \\
\text { terrestrial bioturbation }\end{array}$ \\
\hline HS & $\begin{array}{l}\text { Hetherolithic stratification: } \\
\text { interbedded fine-grained } \\
\text { sandstones and siltstones and } \\
\text { mudstones; and very fine to } \\
\text { medium-grained reworked } \\
\text { tuffs }\end{array}$ & $\begin{array}{l}\text { Horizontal lamination or } \\
\text { ripple- cross lamination; and } \\
\text { massive }\end{array}$ & $\begin{array}{l}\text { Blades, angiosperm leaves, } \\
\text { Sphenophytes stem }\end{array}$ & $\begin{array}{l}\text { Carbonaceous remains, root } \\
\text { traces }\end{array}$ & $\begin{array}{l}\text { Deposition of epiclastic and } \\
\text { reworked pyroclastic material with } \\
\text { alternation in depositional } \\
\text { conditions in tide-influenced } \\
\text { settings. Subsequent sporadic sub- } \\
\text { aereal exposure and pedogenic } \\
\text { modification }\end{array}$ \\
\hline IHS & $\begin{array}{l}\text { Inclined hetherolithic } \\
\text { stratification: interbedded very } \\
\text { fine- to fine-grained sandstones } \\
\text { and siltstones }\end{array}$ & $\begin{array}{l}\text { Horizontal lamination or } \\
\text { ripple cross lamination; and } \\
\text { massive or laminated. Soft- } \\
\text { sediment deformation }\end{array}$ & $\begin{array}{l}\text { Palaeophycus tubularis, } \\
\text { Planolites montanus, Skolithos } \\
\text { isp, Ophiomorpha isp., } \\
\text { Asterosoma isp., Teichichynus } \\
\text { rectus, Chondrites isp }\end{array}$ & Mud drapes & $\begin{array}{l}\text { Lateral meander migration in tide- } \\
\text { influenced settings. Subsequent } \\
\text { marine bioturbation }\end{array}$ \\
\hline $\mathrm{Fl}$ & Siltstones & Horizontal lamination & Celliforma isp. & $\begin{array}{l}\text { Carbonaceous remains, blades, } \\
\text { slickensides, rhizoliths, } \\
\text { mottling }\end{array}$ & $\begin{array}{l}\text { Settling from suspension. } \\
\text { Occasional sub-aereal exposure, } \\
\text { incipient pedogenic modificaction } \\
\text { and terrestrial bioturbation in fuvial } \\
\text { settings }\end{array}$ \\
\hline Fm & Siltstones & Massive to laminated & - & $\begin{array}{l}\text { Rhizoliths, mottling, Fe- } \\
\text { nodules, slickensides, } \\
\text { carbonaceous remains }\end{array}$ & $\begin{array}{l}\text { Settling from suspension with sub- } \\
\text { aereal exposure and pedogenic } \\
\text { modificaction in tide- and fluvial- } \\
\text { influenced settings }\end{array}$ \\
\hline
\end{tabular}


Table 2

Synthesis of the facies associations.

\begin{tabular}{ll}
\hline Facies association (FA) & Sedimentologic features \\
\hline $\begin{array}{c}\text { Subtidal-Intertidal } \\
\text { deposits (FA1) }\end{array}$ & $\begin{array}{l}\text { Marine bioturbated Tw deposit without an exposed } \\
\text { base with irregular top surfaces and a minimum } 0.5 \mathrm{~m}-\end{array}$ \\
& thick, cover by lenticular deposits of Sb facies with \\
& variable thickness between 0.30 and $0.80 \mathrm{~m}$ and a \\
& lateral extension of several kilometres \\
& Vertically stacked (up to $3 \mathrm{~m}$ in thickness) ribbon-like \\
bidal creek deposits (FA2) & HS facies giving a finning-upward trend. Individual \\
& bodies of Tw facies have thicknesses between 0.5 and \\
& 2 m with sharp, irregular and slightly erosive basal \\
& surfaces \\
Interbedded sheets with a maximum thickness of $2 \mathrm{~m}$ of \\
centimeter-thick sheet-like bodies with flat-basal \\
Tidal flat deposits (FA3) & surfaces of Sm facies, broad centimeter-thick ribbon- \\
& like bodies with undulating basal surfaces of Sr facies \\
& and centimeter-thick of Fm facies. Mud drapes are \\
present
\end{tabular}

Tidal channel deposits (FA4) Channelized bodies composed of narrow sheets of St facies with thickness ranging from 0.3 to $1 \mathrm{~m}$ organized in finning-upward packages with slightly erosive concave-up basal surfaces, and narrow sheets or broad ribbons of Sp facies with thickness ranging from 0.3 to $2.5 \mathrm{~m}$. Reactivation surfaces, mud drapes and muddy rip-up clasts are present

Tidal sand flat deposits (FA5) Finning- and thinning-upward sheet bodies composed of marine bioturbated Sh facies limited by irregular to sharp basal surfaces with thickness ranging from 0.5 to $1.7 \mathrm{~m}$. Muddy intraclasts and mud drapes are presents. Sheet bodies composed of TS facies have thicknesses between 0.8 and $1 \mathrm{~m}$

Marsh deposits (FA6) Sheet bodies of HS facies ranging in thickness from $<0.5 \mathrm{~m}$ to $6 \mathrm{~m}$ and more than $900 \mathrm{~m}$ in length, and sheet bodies of Tw facies with up to 2.2 m-thick and with a lateral extension of kilometer-scale organized with a finning-upward trend. Root traces are present

Tidal point bar deposits (FA7) IHS facies $11 \mathrm{~m}$ in thickness and laterally continuous and 0.4 m-thick sheets of Fm facies with an upwardfinning trend. Mud drapes, bidirectional crossstratification and soft-sediment deformation are present

Fluvial channel deposits (FA8) Isolated bodies of Gm, Gt, St, Sp and Sm facies with narrow to broad sheet- to ribbon-like shapes, with irregular flat slightly erosive basal surfaces and internally with a finning-upward trend. The thickness ranges between 1.5 and $7 \mathrm{~m}$. Intraclasts are observed

Fluvial point bar deposits (FA9) Finning-upward packages of $2 \mathrm{~m}$ thick and less than $80 \mathrm{~m}$ wide unit composed of Sl facies with individual dipping beds with $0.4-0.5$ m-thick. Paleoedaphic features are present

Floodplain deposits (FA10)

Pyroclastic and volcaniclastic deposits of the floodplain (FA11) Stacks of narrow sheets of Sm and Fm facies with bases mainly planar and sharp and sporadically irregular and thickness between 0.3 and $<2 \mathrm{~m}$; and sheet bodies of 0.5 $-<2 \mathrm{~m}$ thick with planar and sharp contacts of $\mathrm{Sl}$ and $\mathrm{Fl}$ facies. Finning-upward trends and paleoedaphic features are observed

$\begin{array}{ll}\begin{array}{l}\text { Ichnofacies and paleontological } \\ \text { contain }\end{array} & \begin{array}{l}\text { Interpretation and depositional } \\ \text { setting }\end{array} \\ \begin{array}{l}\text { Skolithos-Cruziana ichnofacies. Oysters } \\ \text { (Crassostrea orbigny) and other marine }\end{array} & \begin{array}{l}\text { Bars and bioherms or reefs } \\ \text { developed in the subtidal } \\ \text { mollusks }\end{array} \\ \begin{array}{l}\text {-intertidal setting of a coastal } \\ \text { environment as the outer part of an } \\ \text { estuary }\end{array} \\ \begin{array}{l}\text { Volcaniclastic infill of small, low- } \\ \text { hierarchy tidal channels (tidal } \\ \text { creeks) developed in the intertidal } \\ \text { ichnofacies. Terrestrial mammals }\end{array} & \text { zone of an estuarine environment }\end{array}$

Glossifungites ichnofacies

Alternation of bed load transport and deposition of sand and flocculated fluid muds with fluctuating tidal current energy in shallow flat areas as tidal flat settings that developed in the center of an estuary Migration of subaqueous 3D- and 2D-dunes within channels formed in moderate to high energy environments with tidal influence as the subtidal part of the tidal channels in the central to inner part of an estuary

Deposits of high-energy that developed in shallow, tidally dominated systems, near to the "turbidity maximum" as tidal sand flats of the outer parts of the central estuary

Blades, angiosperm leaves, Sphenophytes stem

Depositional transition from peak to standstill flow of reworked pyroclastic material (Tw) and epiclastic material (HS) in a flatlying area as salt marshes or marshes developed in an estuary. Subsequent pedogenesis Tidal deposits as point bars developed in meandering channels in the fluvial-tidal zone of an estuary

Infill of fluvial single, fixed and laterally stable channels

Blades, angiosperm leaves

Palaeophycus tubularis, Celliforma isp.

Depauperate Skolithos-Cruziana ichnofacies

$-$

Laterally accreting point bar deposits of fine-grained (counter point bars) in low-energy meandering channels in fluvialdominated settings near the landward limit of the tidally influenced estuary. Subsequent pedogenesis

Multiple flooding events of unconfined flows developed on a floodplain where the sediments were transported as bedload (sandy facies) and suspension components (muddy facies). Subsequent pedogenesis and bioturbation $\mathrm{T}$ facies represent event of ash-fall in sub-aerial and subaqueous settings in floodplain environments. Tw represent unconfined sheet-flood episodes that remobilized pyroclastic materials in floodplain environments. Subsequent pedogenesis 
Table 3

Summary of trace fossil assemblages and its environmental significance.

\begin{tabular}{|c|c|c|c|c|c|}
\hline Unit & $\begin{array}{l}\text { Trace fossil } \\
\text { assemblages }\end{array}$ & Ichnofossils and bioturbation index & Ichnofacies and environmental significance & Facies & Facies association \\
\hline $\begin{array}{l}\text { Monte León } \\
\text { Formation }\end{array}$ & TFA1 & $\begin{array}{l}\text { Moderately diverse, moderately highly } \\
\text { bioturbated (BI } 4 \text { ). Dominated by Ophiomorpha } \\
\text { isp. and cf. Phycosiphon }\end{array}$ & $\begin{array}{l}\text { Skolithos-Cruziana ichnofacies. Impoverished } \\
\text { marine communities. Soft substrates. Fresh } \\
\text { water input, salinity fluctuations to more stable } \\
\text { marine conditions. }\end{array}$ & Tw & FA-1 \\
\hline \multirow[t]{6}{*}{$\begin{array}{l}\text { Santa Cruz } \\
\text { Formation }\end{array}$} & TFA2 & $\begin{array}{l}\text { Scarcely diverse, scarcely bioturbated (BI 2). } \\
\text { Dominated by Ophiomorpha isp. with } \\
\text { subordinated elements of Skolithos isp. and } \\
\text { Palaeophycus tubularis }\end{array}$ & $\begin{array}{l}\text { Depauperate Skolithos-Cruziana ichnofacies. } \\
\text { Impoverished marine communities. Soft } \\
\text { substrates. Fresh water input with persistent } \\
\text { salinity fluctuations. }\end{array}$ & Tw & FA-2 \\
\hline & TFA3 & $\begin{array}{l}\text { Scarcely diverse, intensity of bioturbation } \\
\text { highly variable (BI 0-3), Dominated by bivalves } \\
\text { vertical dwelling structure and Arenicolites isp. }\end{array}$ & $\begin{array}{l}\text { Glossifungites ichnofacies. Impoverished marine } \\
\text { communities Firm substrates. }\end{array}$ & $\mathrm{Sm}, \mathrm{Sr}$ & FA-3 \\
\hline & TFA4 & Scarcely diverse and scarcely bioturbated (BI 0 & Depauperate Skolithos ichnofacies. & St, Sp & FA-4 \\
\hline & & $\begin{array}{l}\text {-1). Composed by Ophiomorpha isp. and } \\
\text { abundant isolated fecal pellets }\end{array}$ & $\begin{array}{l}\text { Impoverished marine communities. Soft } \\
\text { substrates. Persistent salinity fluctuations. } \\
\text { High-energy environment. }\end{array}$ & Sh & FA-5 \\
\hline & TFA5 & $\begin{array}{l}\text { Moderately diverse, locally moderately } \\
\text { bioturbated (BI 3). Dominated Palaeophycus } \\
\text { tubularis, Planolites montanus, and Skolithos isp., } \\
\text { subordinate elements are Ophiomorpha isp. } \\
\text { Chondrites isp. is locally abundant }\end{array}$ & $\begin{array}{l}\text { Depauperate Skolithos-Cruziana ichnofacies. } \\
\text { Soft substrates. Variation in the degree of } \\
\text { bioturbation associated with changing salinity } \\
\text { and elevations of the subtidal-intertidal zone }\end{array}$ & IHS & FA-7 \\
\hline & TFA6 & $\begin{array}{l}\text { Scarcely diverse and scarcely bioturbated (BI } 0 \\
-1 \text { ). Dominated by diverse ferric root traces, } \\
\text { with subordinated Palaeophycus tubularis and } \\
\text { Celliforma isp. }\end{array}$ & $\begin{array}{l}\text { Continental environments. sub-aerial exposure, } \\
\text { pedogenesis and bioturbation. Seasonality, } \\
\text { well-drained paleosoils, occasionally } \\
\text { waterlogged. }\end{array}$ & Sm, Fm, Fl & FA-10 \\
\hline
\end{tabular}

lenticular shape with variable thickness between 0.30 and $0.80 \mathrm{~m}$, and has an exposed lateral extension of several kilometres (Tables 1 and 2). Level of Tw is moderately highly bioturbated (BI 4) making it difficult to identify individual trace fossils, although some Ophiomorpha isp. and cf. Phycosiphon (TFA1) can be seen (Fig. 5A-C, Table 3). Other parts of this Tw bed are highly bioturbated by phycosiphoniform burrows creating a mottled fabric and obscuring other traces (Fig. 5A, Table 3). Burrows of Ophiomorpha isp. are filled by a massive reworked tuff that in turn is commonly reworked by cf. Phycosiphon (Figs. 5B-C, Table 3). However, beds of Sb have no trace fossils associated.

Interpretation: Bioturbated Tw facies of the MLF are interpreted as reworked ash-fall materials transported by the rivers to the tidal channels (e.g. Scasso and del Río, 1987) where they were mixed with other sediments and subject to marine bioturbation. This points to a transitional environment where energy from waves or tidal currents would have reworked the pyroclastic materials that came from contemporaneous explosive volcanism (e.g. Cuitiño and Scasso, 2013). The absence of mud drapes in these deposits suggests deposition by waters with low suspended sediment concentration in a seaward position of the system. Similarly, the record of a moderately diverse ichnofauna ascribed to the Skolithos-Cruziana ichnofacies (Table 3 ) in this facies with a higher degree of bioturbation than other assemblages studied, and including some elements typical of normal marine conditions such as cf. Phycosiphon, suggests possible increasing salinity in a seaward direction or periods of minor salinity fluctuations. On the other hand, oysters like those recorded at $\mathrm{Sb}$ facies of the FA1 can occur both, in shallow marine and estuarine environments (e.g. Kirby, 2001). In particular, the oyster $C$. orbignyi was adapted to inhabiting a hard or soft bottom, and tolerated a wide range of salinity and even subaerial exposure (Griffin and Parras, 2012), suggesting the presence of brackish water (Cuitiño et al., 2013). The prevalence of articulated shells in life position and its occurrence within a sedimentary rock with fine-grained matrix indicate little reworking. The tabular morphology, the lateral continuity and the internally massive bodies suggest colonization and growth of a community forming bioherms or reefs. The low diversity (mainly monospecific) shell accumulations are related to environmental stress, commonly due to fresh-water input in a coastal setting (e.g. Cuitiño et al., 2013). Therefore, Sb facies of the MLF is interpreted as oyster bioherms or reefs developed in settings with shallow water, as in the subtidal to intertidal zone of an estuary. Thus, FA1 represents bars and bioherms or reefs developed in the subtidal-intertidal setting of a coastal environment as the outer part of an estuary (Table 2).

\subsubsection{Facies association 2: tidal creek deposits}

Description: The FA2 of the lowermost SCF is composed of Tw facies that frequently exhibit marine bioturbation (Fig. 4, Table 1). Upsection at both RDB-N and RDB-S, ribbon-like bodies of Tw facies mainly have thicknesses between 0.5 and $2 \mathrm{~m}$ (Figs. 3A, 4 and $5 \mathrm{E}-\mathrm{F}$ ). Basal surfaces of individual bodies are sharp, irregular and slightly erosive. In some cases two or more beds of Tw facies are vertically stacked forming successions up to $3 \mathrm{~m}$ in thickness (Table 2). These levels record trace fossil assemblages (TFA2) highly dominated by networks of Ophiomorpha isp. (Fig. 5E), and subordinated elements of Skolithos isp. and Palaeophycus tubularis (Fig. 4, Table 3). FA2 also contain terrestrial mammals (see below) which are well preserved, unweathered, and in some cases, partially articulated and associated to basal discontinuities of the bodies (Figs. 4 and 5F). These deposits are covered by HS facies (described below) giving a finning-upward trend (Fig. 4).

Interpretation: Tw facies of the lowermost SCF with slightly erosive basal surfaces and ribbon-like shapes are interpreted as the volcaniclastic infill of small channels. The record of extended decapods crustacean burrow systems such as Ophiomorpha isp., with constructional walls in this facies suggests the presence of soft substrates (Table 3). Low diversity of the ichnoassemblage points towards salinity-stressed environments (see below). Taphonomic details of fossil mammals in this facies suggest that the remains are autochthonous materials deposited in the intertidal zone. This facies association is interpreted as low-hierarchy tidal channels deposits. The finning-upward trend from Tw to HS facies also confirms such an interpretation. Thus, FA2 represents tidal creeks developed in lower tidal flats or marshes of an estuarine environment (Table 2). 


\subsubsection{Facies association 3: tidal flat deposits}

Description: FA3 occur in the RDB-N section as: 1) centimeterthick sheet-like bodies with flat-basal surfaces of Sm facies, 2) broad centimeter-thick ribbon-like bodies with undulating basal surfaces composed of Sr facies, and 3) centimeter-thick Fm facies (Table 1). These facies are arranged in interbedded sheets with a maximum thickness of $2 \mathrm{~m}$ (Figs. 4, 6A-B, Table 2). Individual beds show lateral thickness changes. Mud drapes are present in $\mathrm{Sr}$ facies (Fig. 6A). This FA is interbedded with Sh facies of the FA5. The same trace fossil assemblage (TFA3; Table 3) essentially occurs in both Sm and $\mathrm{Sr}$ facies. The intensity of bioturbation is highly variable (BI 0-3) with unbiorturbated beds interbedded with low to medium bioturbated ones (Fig. 6B). Trace fossils consist of vertical dwelling structures of stationary location of suspension feeders or surfacedeposit feeding bivalves and of suspension- or filter-feeding polichaetes (Arenicolites isp.) of various sizes (Figs. 4 and 6A-B, Table 3).

Interpretation: $\mathrm{Sm}, \mathrm{Sr}$ and $\mathrm{Fm}$ facies attest deposition in shallow flat areas with lower flow regime conditions. The interstratification between these facies indicates the persistent alternation of bed load transport and deposition of sand and flocculated fluid muds (Pearson et al., 2012). The occurrence of mud drapes suggests fluctuating current energy and the influence of tidal currents (Dalrymple and Choi, 2007). Sm facies record bivalve and polychaete burrows with sharp wall boundaries infilled by the overlaying sediments, suggesting that colonization occurred on firm substrates possibly exposed by tidal currents (Table 3). Thus, interbedded $\mathrm{Sm}, \mathrm{Sr}$ and $\mathrm{Fm}$ facies of the FA3 are interpreted as deposits of tidal flat settings (e.g. Plink-Bjorklund, 2005) that developed in the center of an estuary (Fig. 4, Table 2).

\subsubsection{Facies association 4: tidal channel deposits}

Description: This FA is composed by St and Sp facies (Table 1). Individual bodies of St facies are narrow sheets with thickness ranging between 0.3 and $1 \mathrm{~m}$. St facies are organized in finningupward packages with slightly erosive concave-up basal surfaces (Figs. 6C and E, Table 2) and are concentrated at the base of channel bodies. Foresets are sometimes marked by mud drapes. Muddy ripup clasts are observed at the base of the sets. The clasts are mostly platy shaped, but also can be rounded or angular (Fig. 6A), and (rarely) imbricated. Paleoflow directions are dominantly to the east-southeast. The bodies of the Sp facies (Figs. 4 and 6A, C and E) show slightly erosive bases, frequently covered by muddy rip-up clasts with similar characteristics to St facies (Figs. 6A and D). Foresets are tangential and are sometimes locally marked by mud drapes (Fig. 6A). Reactivation surfaces are also present. Individual bodies form narrow sheets or broad ribbons with thickness ranging from 0.3 to $2.5 \mathrm{~m}$. This facies is the most common in channelized bodies. Paleoflow directions are dominantly to the southeast with minor south-southwest components; reverse paleocurrent directions are sometimes present. The only trace fossil in St and Sp facies are very fine specimens (BI 0-1) of Ophiomorpha isp. These consist of vertical components (Fig. 6E) with isolated fecal pellets of Ophiomorpha also being abundantly distributed (TFA4; Table 3).

Interpretation: St and $\mathrm{Sp}$ facies were formed in moderate to high energy environments, and are related to migration of subaqueous 3D- and 2D-dunes within channels, as indicated by the basal concave upward erosional bounding surfaces. Also, the internal organization of the succession suggests deposition during waning flow. Mud drapes within cross beds represent intervals of slack water during tidal cycles (Dalrymple and Choi, 2007). The occurrence of mud intraclast is common in the bottom of channel deposits in the middle reach of estuaries, in the vicinity of the "turbidity maximum" (Dalrymple and Choi, 2007) and indicates that the mud of underlying beds was still soft when eroded
(Mackay and Dalrymple, 2011). This is a typical feature of tidal influence (Dalrymple and Choi, 2007). The occurrence of mud drapes and reactivation surfaces in both facies reflect tidal influence (e.g. Dalrymple and Choi, 2007; Mackay and Dalrymple, 2011). The elevated energy of the channels generally reduces the preservation of trace fossils, even though facies-crossing biogenic structures are preserved, such as monospecific assemblages of Ophiomorpha isp. (Table 3). Thus, the features of St and Sp facies of the FA4 together with the presence of brackish ichnofauna allow us to distinguish these channels from a purely freshwater fluvial channel (e.g. Longhitano et al., 2012; Pearson et al., 2012), and allow us to interpret these deposits as the subtidal part of the tidal channels in the central to inner part of an estuary (Table 2).

\subsubsection{Facies association 5: tidal sand flat deposits}

Description: The FA5 is composed of Sh facies (Figs. 4 and 6A and E-F, Table 1), which is arranged in finning- and thinning-upward sheet bodies limited by irregular to sharp basal surfaces with thickness ranging from 0.5 to $1.7 \mathrm{~m}$ (Table 2). Muddy intraclasts and thick mud drapes are sometimes present (Figs. 6A and F). Bioturbation intensity is low (BI 1) with trace fossils occurring sporadically in low numbers. The trace fossil assemblage (TFA4; Table 3) is composed of the vertical components of decapod dwelling structures (Ophiomorpha isp.) and abundant fecal pellets, originally from the walls of the Ophiomorpha specimens (Figs. 4 and $6 \mathrm{~A}$ and $\mathrm{F}$, Table 3 ). In contrast, at RDB-S section are recorded sheet bodies composed of TS facies thickness ranging from 0.8 to $1 \mathrm{~m}$ (Tables 1 and 2). Carbonaceous remains and fossil leaves are recorded in TS facies (Fig. 4; Table 1). The leaves were assigned by Brea et al. (2012) to the Nothofagaceae and are generally undamaged. The TS facies contains no associated marine fossils or root traces.

Interpretation: Sh and TS facies indicate tractive currents and represent upper-flow-regime structures that developed in shallow, tidally dominated systems in the central parts of estuaries, where the "tidal maximum" occurs (Table 2). The presence of thick mud drapes indicates a seaward position respect to the peak of the "turbidity maximum" (Dalrymple and Choi, 2007). The Ophiomorpha traces and its fecal pellets ascrived to the depauperate Skolithos ichnofacies suggest energetic conditions, as does the presence of abundant isolated fecal pellets (Vilas et al., 2010) (Table 3). The lowdiversity and preponderance of vertical traces in these facies suggests brackish-water conditions prevailed (Sisulack and Dashtgard, 2012) with the area being subject to periodic freshwater discharge (Pearson et al., 2012). Such biogenic reworking attests a highenergy environment in which sands were initially deposited and then colonized by different opportunistic invertebrates (Pearson et al., 2012). Similarly, the occurrence of fossil leaves of Nothofagaceae and carbonaceous remains suggests freshwater input and slack-water periods. Thus, FA5 is interpreted as tidal sand flats that developed in the outer parts of the central estuary (Table 2).

\subsubsection{Facies association 6: marsh deposits}

Description: FA6 of the SCF is composed of HS facies (Fig. 4, Table 1). It is arranged as sheet bodies ranging in thickness from $<0.5 \mathrm{~m}$ to $6 \mathrm{~m}$ and more than $900 \mathrm{~m}$ in length (Table 2). HS facies records the finest deposits of the RDB-N. If so a finning-upward trend occurs; a change in thickness of sets success throughout the succession. Carbonaceous remains, blades, angiosperm leaves, and Sphenophytes stem compressions are present (Fig. 4, Table 1). This FA is also composed of sheet bodies of Tw facies (Table 1) with up to 2.2 m-thick and with a lateral extension of kilometer-scale (Table 2) which overlaid HS facies of this FA and IHS facies of the FA7 (Figs. 3C and 4). HS and Tw facies have no associated marine trace fossils; root traces occur in both RDB-N and RDB-S sections. 

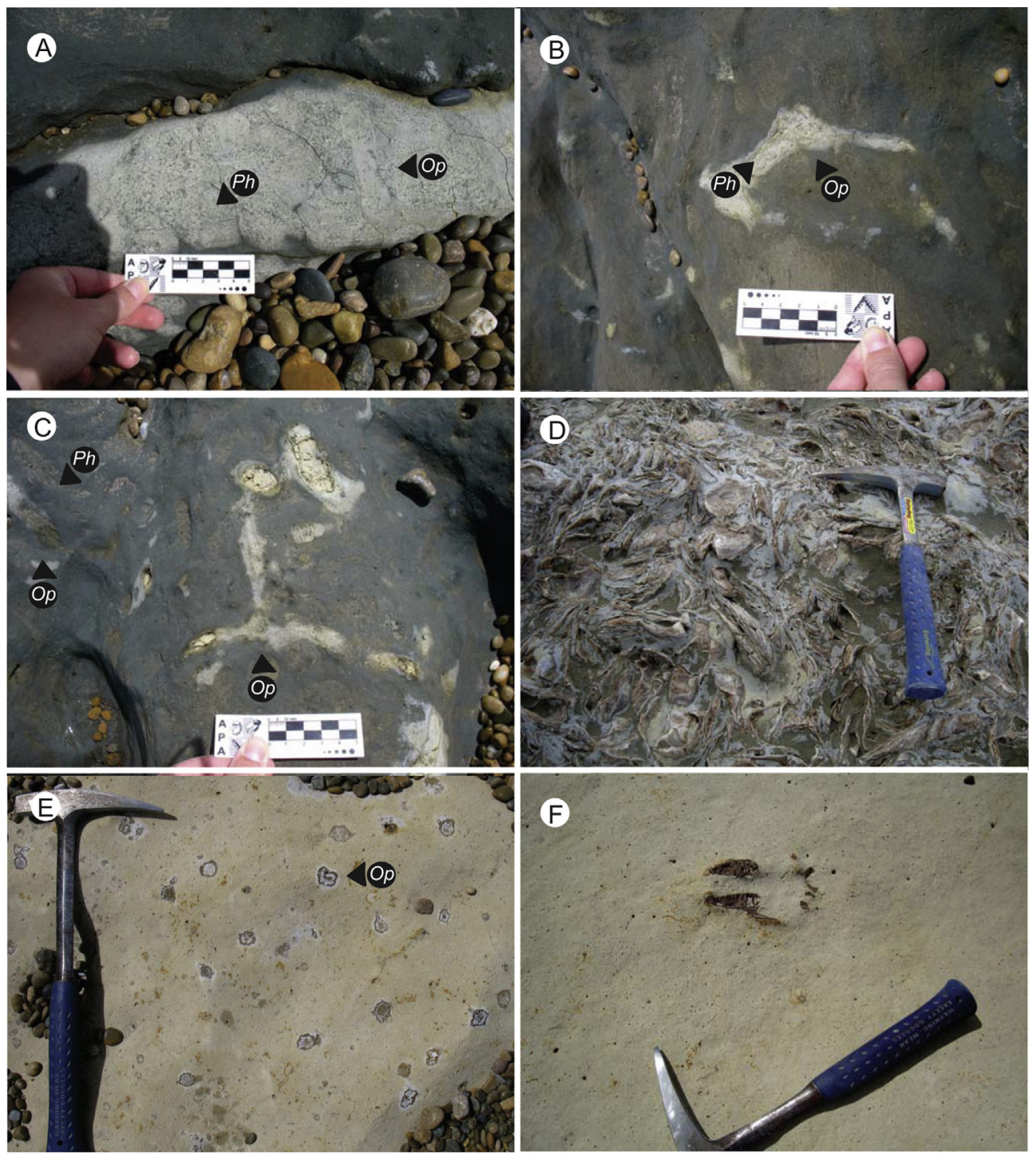

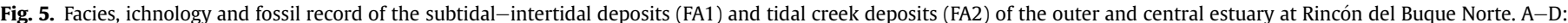

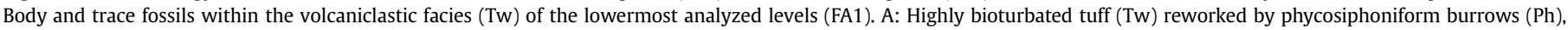

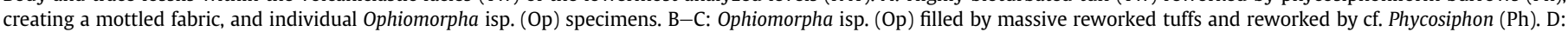

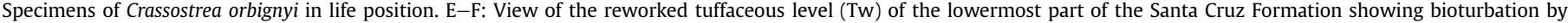
Ophiomorpha isp. (Op), and the presence of terrestrial mammal fossils (FA2).

Interpretation: Sheet morphology and lateral continuity of the bodies suggest deposition of reworked pyroclastic material (Tw) and epiclastic material (HS) in a flat-lying area. Rhythmic interbedding indicates a depositional transition from peak to standstill flow. Changes in the thickness of HS indicate that tidal currents are the main depositional process (e.g. Santos and Rosetti, 2006). The occurrence of root traces, blades, angiosperm leaf compressions and other carbonaceous remains suggest freshwater discharge, and the preservation of these is indicative of immature plain setting as brackish floodplain or immature-wetland deposition (e.g. Pearson et al., 2012). However, Sphenophytes stem compressions belong to the genus Equisetum (Page, 1972; Channing et al., 2011) (Iglesias, pers. com.) and show similar characteristics to the extant species Equisetum giganteum. The latter exhibits high salinity tolerance. It grows in coastal northern Chile $\left(\sim 18-20^{\circ} \mathrm{LS}\right)$ in saline soils and includes some of the few low elevation $(3-90 \mathrm{~m})$ populations known for this species (Husbi, 2009). Probably the lack of infaunal marine trace fossils in this FA could correspond to a system that possessed a high ground-water table but still under tidal influence (e.g. Person et al., 2012). Root traces suggest reworking by vegetation and deposition in freshwater floodplains or salt marshes (e.g. Pearson et al., 2012). Thus, FA6 indicates the presence of a salt marsh developed in an estuary (Table 2). This environment might have been associated with marshes, especially upsection at RDB, where root marks were observed.

\subsubsection{Facies association 7: tidal point bar deposits}

Description: FA7 occur exclusively at RDB-S section and is composed of millimeter-to centimeter-thick interbedded $\mathrm{Sh}, \mathrm{Sr}$ and Fm facies that form an inclined hetherolithic stratification $11 \mathrm{~m}$ in thickness (IHS facies) (Figs. 3C, 4 and 7, Tables 1 and 2). IHS facies are laterally continuous and have an upward-finning trend. IHS sets dip to the north-northeast with angles around $14^{\circ}$; up section there is a decrease in the dip to an average of $7^{\circ}$ (Fig. 3C). Sedimentary structures are partially obliterated by bioturbation, and the walls of the burrows are oxidized and coated with dark yellowish orange 

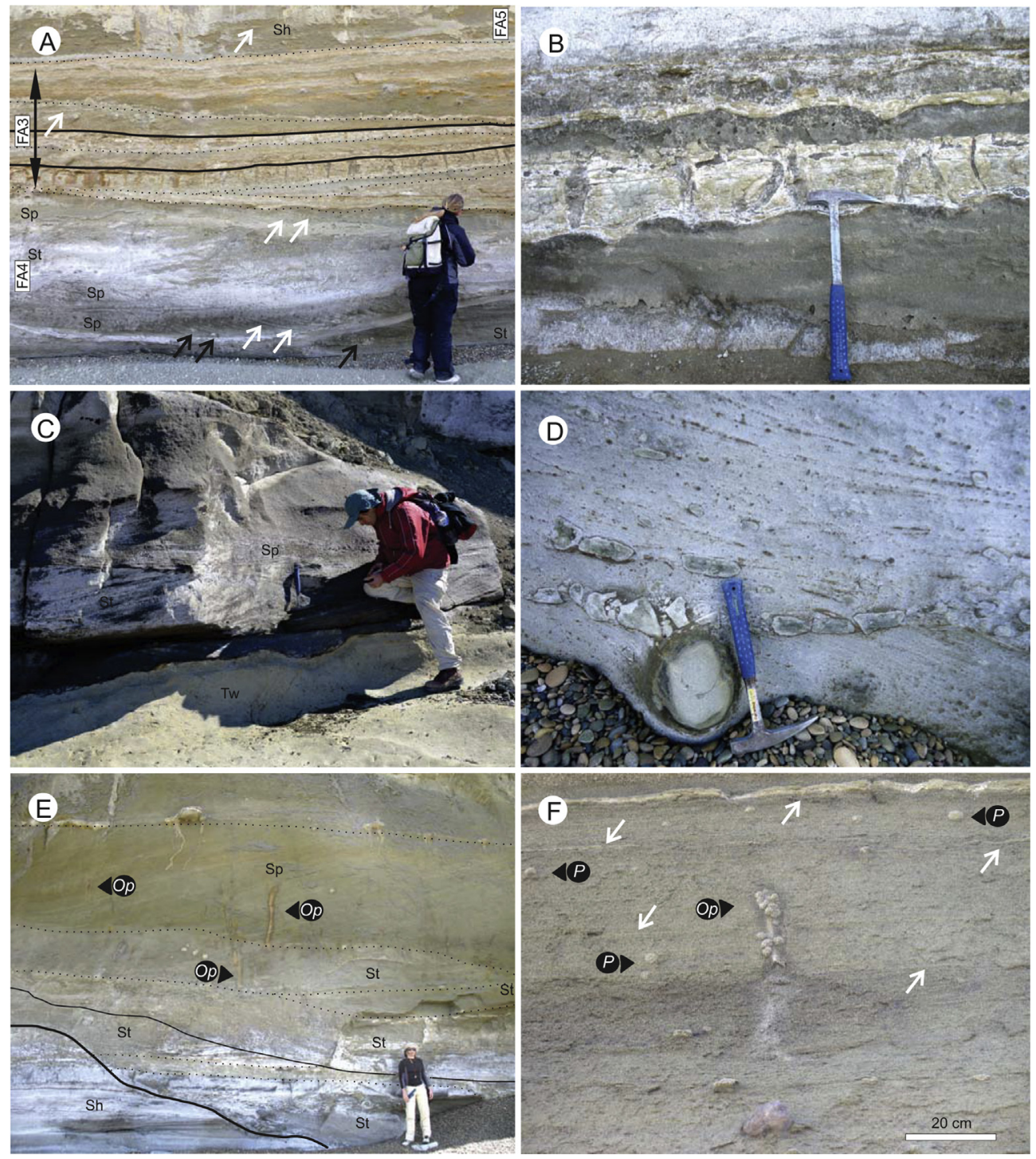

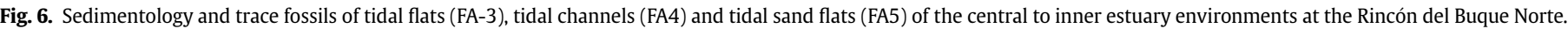

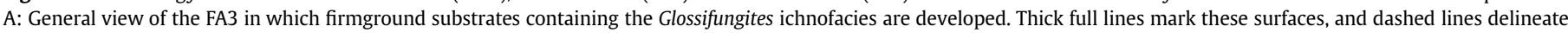

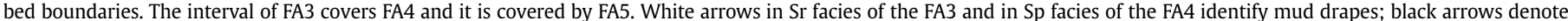

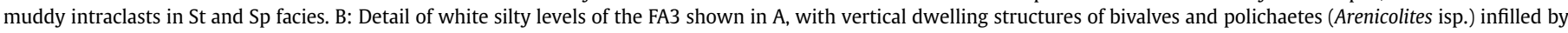

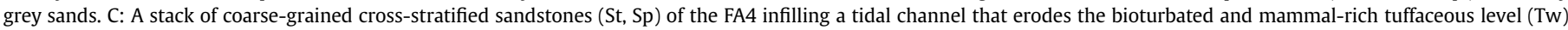

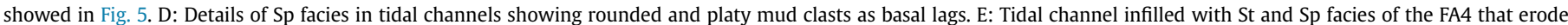

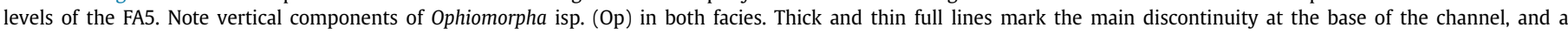

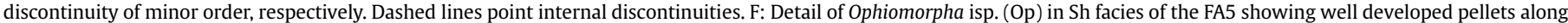
the vertical shaft. Note the presence of dispersed fecal pellets (P). The arrows mark mud drape levels.

iron hydroxide (Fig. 7A-D). Mud drapes are in some cases rich in black organic material and in other cases are oxidized (orange) (Fig. 7F). Locally, the cross sets show bidirectional crossstratification (Fig. 7F). Soft-sediment deformation occurs in the IHS facies (Figs. 4 and $7 \mathrm{~A}-\mathrm{D}$ and $\mathrm{G}-\mathrm{H}$ ): Convoluted bedding shows that the anticlinal folds are overturned in a downslope direction (Fig. 7G). Local increases in bioturbation intensity occur, especially upward. Bioturbation is mostly low but occasionally medium in intensity (BI 3). The trace fossil assemblage (TFA5; Table 3) is dominated by the polichaete dwelling and feeding structures Palaeophycus tubularis, Planolites montanus, and Skolithos isp. (Fig. 7A and D). Subordinate elements are decapod dwelling structures (Ophiomorpha isp.), and worm feeding structures such as those of Asterosoma isp. and Teichichynus rectus (Figs. 7A-C, Table 3). The latter one can also be interpreted as an equilibrium structure. On fine-grained sandstone and siltstone beds Chondrites isp is locally abundant (Figs. 7B-C, Table 3). IHS sets are capped with $\sim 0.4$ m-thick sheets of Fm facies with no trace fossils.

Interpretation: As with the HS facies of FA6, the interbedded sands and silts of FA7 are interpreted as tidal deposits (e.g. Johnson and Dashgard, 2014). Sisulak and Dashtgard (2012) point out that sands of IHS are deposited during the freshet whilst muds are deposited during waning freshet flow. The occurrence of mud drapes in Sr beds attest that mud was settling during of slack water. Reversing current directions on cross-laminated levels reflect tidal influences. Both features characterize fluvial-tidal transitions (e.g. Dalrymple and Choi, 2007) as are drapes rich in terrestrial organic material (Van den Berg et al., 2007). Similarly, oxidized drapes and wall of burrows are formed in the upper intertidal zone of the bars of a tidal-fluvial transition (Choi et al., 2004) and the observed convolute bedding may be triggered by waves and by gravitydriven downslope movement in tidal bars (Choi et al., 2004). The 
almost exclusive record of infaunal trace fossils in the whole finning-upward succession denotes burrowing as a strategy for surviving in environments with salinity fluctuations. In addition, the small size of trace fossils suggests brackish water conditions. Variations in the degree of bioturbation throughout the deposit are associated with changing elevations in the subtidal to intertidal zone (Choi et al., 2004) and variable salinity (Johnson and Dashgard, 2014) (Table 3). IHS facies also are related to lateral accretion on tidally influenced points bars (tidal bars) (e.g. Choi et al., 2004; Dalrymple and Choi, 2007; Johnson and Dashgard, 2014), probably associated with and laterally infill in high-sinuosity channels (e.g. Plink-Bjorklund, 2005; Longhitano et al., 2012; Scasso et al., 2012). The scale of the IHS reinforces the interpretation that it corresponds to point bars developed in meandering channels in the fluvial-tidal zone of an estuary (Choi et al., 2004; Dalrymple and Choi, 2007) (Table 2). In this context, Fm facies in the upper part of the IHS are interpreted as fine deposits that finish with the upward-finning grain size trend (e.g. Choi et al., 2004), reflecting the decrease in flow velocity associated with decreasing water depths (Johnson and Dashgard, 2014).

\subsubsection{Facies association 8: fluvial channel deposits}

Description: This facies association is composed of coarsegrained deposits consisting of isolated bodies of sand and gravel with narrow to broad sheet-to ribbon-like shapes, which show irregular flat slightly erosive basal surfaces (Fig. 3A-B and 8A, Table 2). In some cases intraclasts are observed. The thickness of such deposits ranges between 1.5 and $7 \mathrm{~m}$. The thicker bodies occur in RDB-N (Fig. 4). Internally the thicker bodies show a finningupward trend from Gm, Gt or St to Sp facies (Table 1). Thinner beds are composed of St or Sm facies and fine upwards from coarseto fine-grained sandstone. Such deposits are interbedded with floodplain deposits of FA10.

Interpretation: Taking in consideration the geometry, finningupward trends, and slightly erosive character of the basal surfaces of these coarse-grained facies, these are likely single story fluvial channel deposits (e.g. Bridge, 2003; Gibling, 2006). The occurrence of Gt, St, and Sp facies suggests prevalence of tractive deposition from dilute flows (Umazano et al., 2012), which represent migration of gravely, and sandy three-dimensional dunes (Gt, St), and migration of sandy two-dimensional dunes (Sp). Gm facies at the base of the bodies are lag deposits (e.g. Miall, 1996). However, the lack of structures in some bodies may indicate that the channel flow was heavily laden with sediment relative to its competence, resulting in suppression of bedform development (Fisher et al., 2007), or even may indicate that sedimentary structures were lost by weathering/pedogenesis. The fining-upward nature and the lack of structures up section of some of these channels indicate a decrease in flow velocity and suggest that the mechanism of transport change from bedload to suspended load. The interbedded floodplain deposits suggest that during times of peak discharge, unconfined overbank flow was important. The absence of evidence for sub-aerial exposure and of internal surface (reactivation or lateral migration surfaces) suggests that the channels were fixed and laterally stable (Table 2 ). The record of channel margin vegetation in the basal levels of the SCF (Brea et al., 2012), may have stabilized the channel banks and inhibited channel avulsion or migration to different positions (Nichols and Fisher, 2007).

\subsubsection{Facies association 9: fluvial point bar deposits}

Description: Large scale cross-stratification was observed at basal-middle part of the RDB-S section (Figs. 3C, 4 and 7E). This FA is characterized by a $2 \mathrm{~m}$ thick and less than $80 \mathrm{~m}$ wide unit that is dominated by finning-upward packages composed of $\mathrm{Sl}$ facies (Table 1). Individual dipping beds are $0.4-0.5 \mathrm{~m}$-thick. The inclination of the large-scale strata varies from 6 to $11^{\circ}$ and the dip direction is towards the south-southwest (Fig. 7E). Fossil leaves of angiosperms (Iglesias, pers. com.), carbonaceous remains, blades, and paleoedaphic features (slickensides and root traces) were recorded in large-scale cross-stratified bodies.

Interpretation: Large-scale cross-stratified bodies are interpreted as laterally accreting point bar deposits in meandering channels (Table 2). The fine grain size of the Sl facies of such deposits is related to fine-grained dominated counter point bars deposits that form by lateral accretion in low-energy meandering rivers under tidal influence (Fig. 9) (e.g. Smith et al., 2009). The occurrence of deposits assigned to point bars or counter point bars in the lower-middle part of the section of the SCF at RDB-S, implied that some channels migrated laterally to some degree (Glibbing, 2006). The absence of marine fossil traces in this deposit and its relation with deposits of FA6 (marsh deposits) and FA10 (floodplain deposits) attest fluvial-dominated settings near the landward limit of the tidally influenced estuary (see Fig. 9) (e.g. Johnson and Dashgard, 2014) (Table 2).

\subsubsection{Facies association 10: floodplain deposits}

Description: This FA is composed of fine epiclastic facies, which consist of narrow sheets of Sm and Fm facies (Fig. 4; Table 1). The base of the bodies is mainly planar and sharp; however, irregular bases were sporadically observed. The thickness of Sm and Fm bodies varied between 0.3 and $<2 \mathrm{~m}$ (Table 2). Sm and Fm commonly have paleoedaphic features, which include vertical rhizoliths, simple dwelling trace fossils, mottling, Fe-nodules, slickensides, carbonaceous remains and carbonate concretions (Figs. 4 and 8B-F). In general these facies show absence of horizons and are apedal; however, blocky structure is present up section in the RDB-S profile (Fig. 8C). Rhizoliths are the most common paleoedaphic feature recorded at the three measured sections. They are mostly ferric having a reddish-brown to yellow-brown color within the root infill and/or on its margins, forming haloes (Fig. 8B). The complete extension of a single root is difficult to observe, although some are delicate and tapering downwards others have constant diameter subtly tapering downwards and with horizontallyinclined secondary root traces (Fig. 8E). Rhizoliths show different combinations of the root infills and haloes. A root trace can be: 1) a discolored, 1-2 $\mathrm{mm}$ in diameter with a continuous brownish yellow halo 4-5 mm diameter (Figs. 8B), 2) a reddish to dark brown root infill of $1-2 \mathrm{~mm}$ with the halo absent or only locally developed (Figs. 8D), 3) a dark reddish brown root infill 1-2 $\mathrm{mm}$ in diameter surrounded by a pale brown to yellow concentric halo $4-10 \mathrm{~mm}$ of diameter.

Trace fossils are scarce and localized in some horizons. Mostly they consist of simple dwelling structures as in Palaeophycus tubularis (TFA6; Table 3). Carbonate concretions are abundant as isolated features or as rods and consolidated horizons frequently in the contacts between sandy and silty beds (Fig. 4). They appear in fine-grained facies and less commonly in Fl facies and in Sl facies. In both cases the latter have paleoedaphic features (Fig. 4). Sl and Fl facies occur in sheet bodies of 0.5 to $<2 \mathrm{~m}$ thick with planar and sharp contacts (Table 2). Finning-upward trends are observed in the interbedded sandstones and siltstones associations. Paleoedaphic features of $\mathrm{Sl}$ and $\mathrm{Fl}$ facies include vertical rhizoliths, simple dwelling and nesting trace fossils, and sporadic mottling, slickensides, and carbonaceous remains. The pedogenic features are highly comparable with those described above and, in addition, contain records of small cells of solitary digging bees, $3-5 \mathrm{~mm}$ wide and 8-10 mm long, assigned to Celliforma isp. (Figs. 4 and 8F, Table 3), with the same characteristics as those found in the SCF south of Río Coyle at Cañadón las Totoras (Krapovickas, 2012; Raigemborn et al., 2012). 

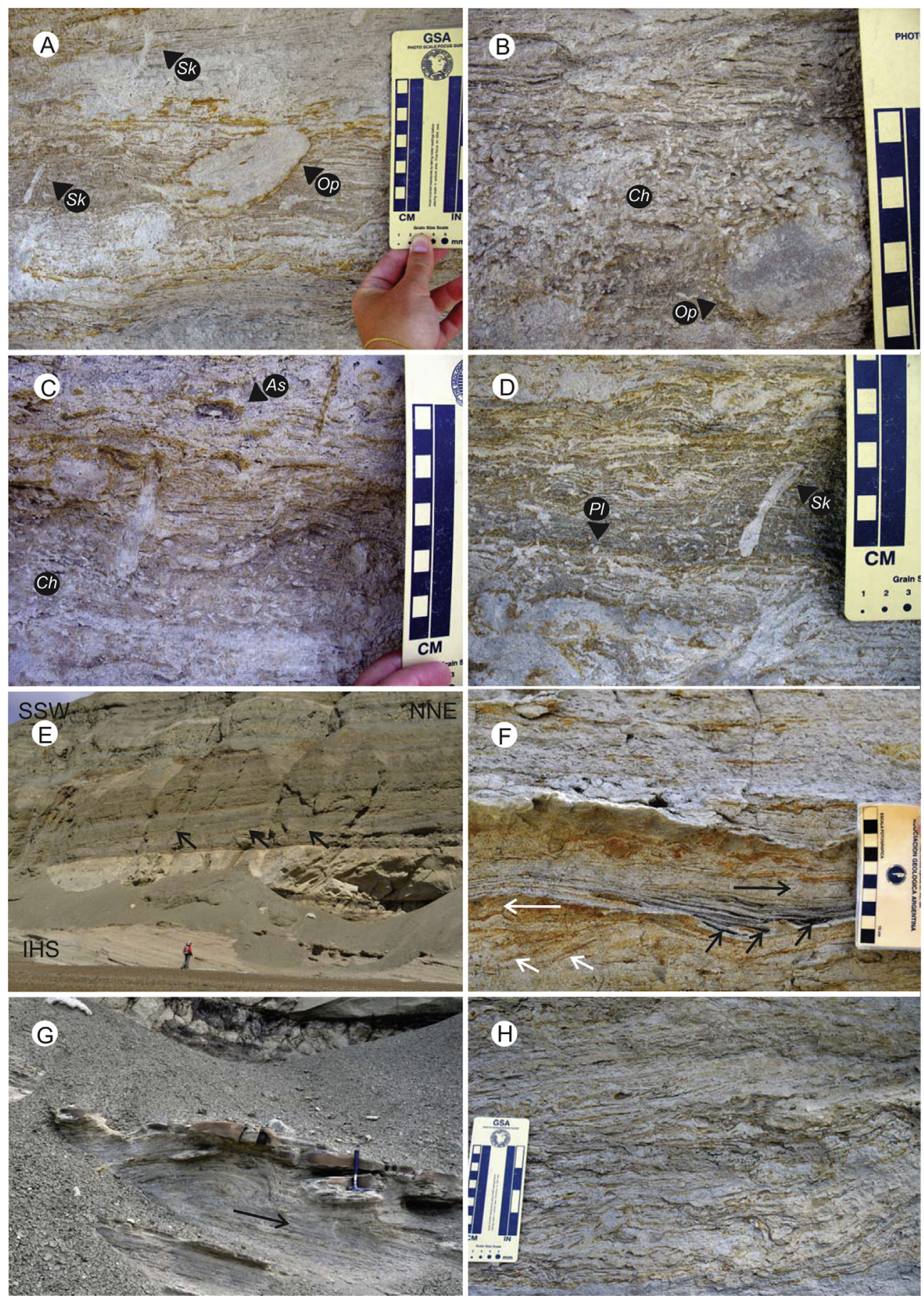

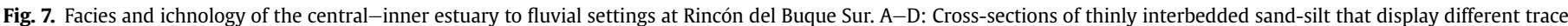

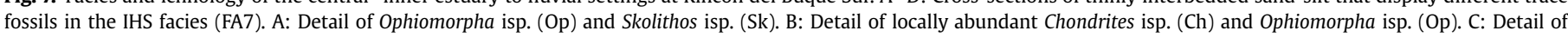

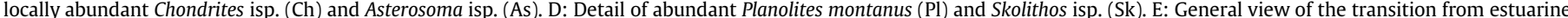

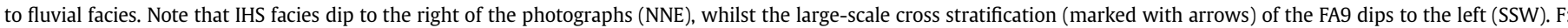

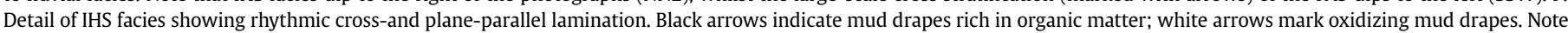

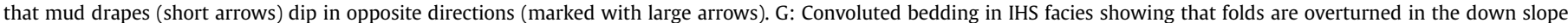
direction marked with an arrow. H: Structures of soft-sediment deformation in an interval within IHS facies.

Interpretation: The sheet-like geometry of the sandy bodies of the fine-grained facies together with the lack of structures of lowflow regime suggests unconfined flows developed on a floodplain (Table 2). This interpretation is reinforced by the dominance of massive and laminated sheet-flood deposits (facies $\mathrm{Sm}$ and $\mathrm{Sl}$ ), which occur during periods of high discharge when large quantities of sediment was transported in turbulent and unconfined sub- aerial flow (Fisher et al., 2007). The sediments loads of these flows were transported as bedload (sandy facies) and suspension components (muddy facies). A change from massive to laminated facies could be in response to the wane of flow velocity. The finest facies (Fm, Fl) with sheet-like shapes and non-erosive bottoms attest deposition under predominantly low energy, sub-aerial conditions from an unconfined flow (Tunbridge, 1981). Finning- 
upward trends are interpreted as an increase in the distance from source or to the gradual reduction of the discharge from tractive conditions ( $\mathrm{Sm}, \mathrm{Sl}$ ) to settling ones $(\mathrm{Fm}, \mathrm{Fl})$. The planar-base nature of the deposits suggests that the flow surface was relatively competent, possibly being stabilized by surface vegetation, as the described by Brea et al. (2012) for the SCF to the south of the Río Coyle area; or indurated after a period of sustained sub-aerial exposure (Fisher et al., 2007), as the edaphized and bioturbated facies described by Krapovickas (2012) and Raigemborn et al.
(2012) for the SCF to the south of the Río Coyle area. The large number of individual deposits that stack to form deposits of the fine-grained facies indicates deposition from multiple flooding events (Table 2). The relationship between these facies and the coarse-grained facies supports this interpretation of multiple sheet-flood events having occurred. Paleoedaphic features and burrows in the finest facies attest intervals of insignificant or absent deposition in which sub-aerial exposure gave place to pedogenesis and bioturbation. Thus, massive appearance of some levels of the
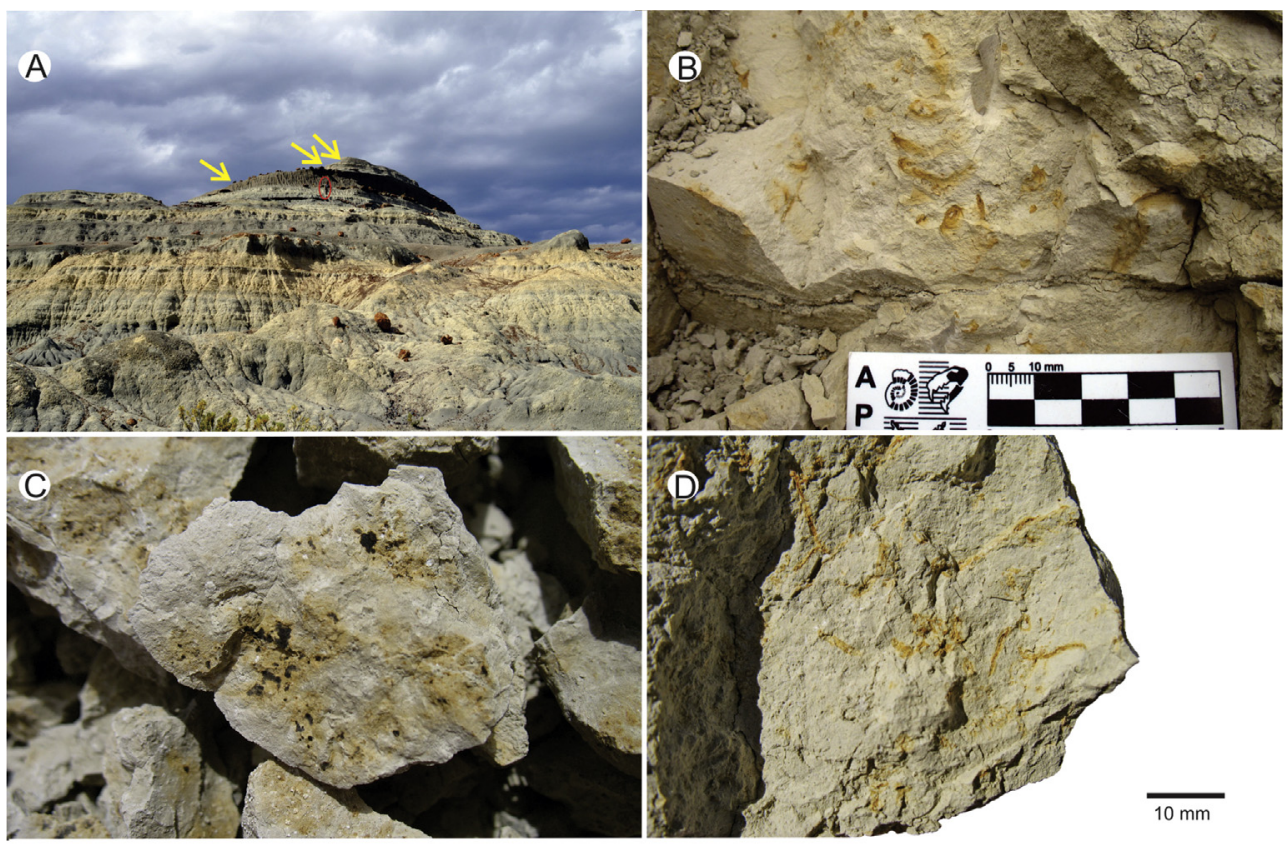

E

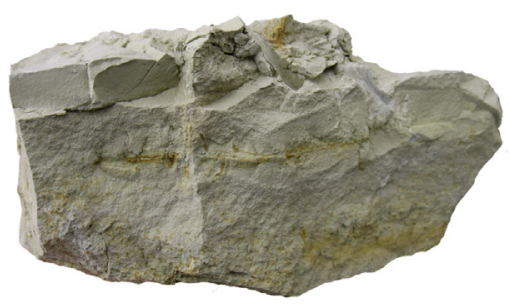

$\mathrm{F}$
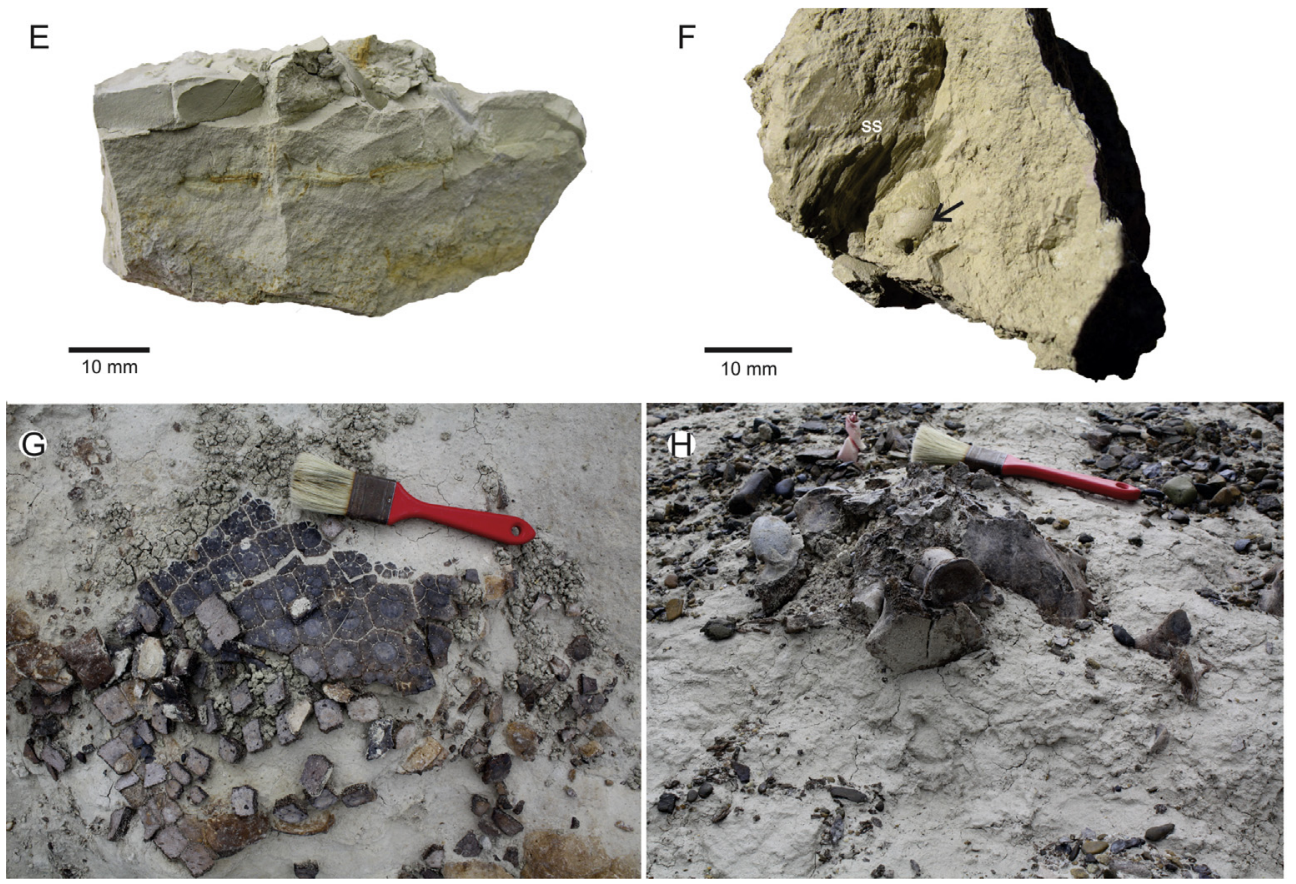

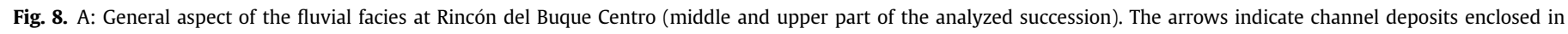

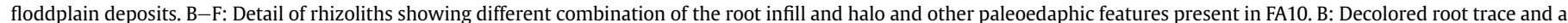

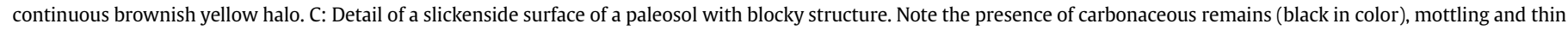

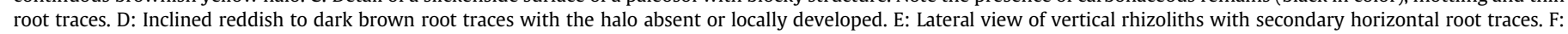

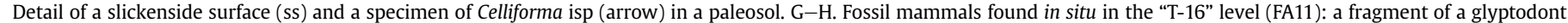

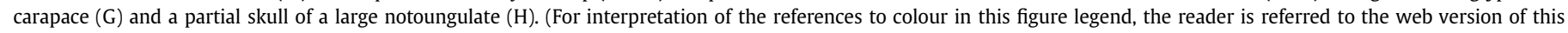
article.) 
finest facies of this FA may indicate reworking by biota and pedogenesis following deposition. In this sense, the abundance of carbonate concretions indicates an excess of alkaline solutes and precipitation in a well-drained floodplain (Retallack, 2001). In addition, burrowing bees generally nidify in arid conditions or in soils with only moderate plant growth, good drainage, and limited exposure to the sun (Ratcliffe and Fagerstron, 1980; Genise and Bown, 1994). Mottling and slickensides suggest periodic waterlogging, with alternating humid and dry stages or seasons. Moreover, the presence of ferric root traces and Fe-nodules implies that the B-horizons of the soil were moderately well drained (Kraus and Hasiotis, 2006). Iron is reduced and mobilized when the soil is water-saturated, and oxidized and immobilized when the soil dries, precipitating in places open to oxygen circulation (Duchaufour, 1987; Kraus and Aslan, 1993; PiPujol and Buurman, 1994). All these processes took place in a setting with a certain degree of seasonality as waterlogged paleosols with hydromorphic features vertically stacked with relatively dry, well-drained paleosoils were carbonate concretions and cells of solitary bees occur.

\subsubsection{Facies association 11: pyroclastic and volcaniclastic deposits of the floodplain}

Description: Pyroclastic and volcaniclastic facies of the FA11 are characterized by the occurrence of $\mathrm{T}$ and Tw facies (Table 1 ). Both facies have sharp nonerosional basal surfaces. They occur as broad sheets ranging in thickness from 0.5 to $1.4 \mathrm{~m}$ interbedded within floodplain deposits (Table 2). Sporadically, paleoedaphic features such as vertical rhizoliths are found at the top of Tw bodies (Fig. 4). One level of yellowish gray $\mathrm{T}$ facies occurs in the middle part of three measured sections of the Rincón del Buque area, making it $\sim 13 \mathrm{~km}$ in lateral extension and 0.7-1.3 m thick (Figs. 3B, 4 and 11, Table 2). Fossil mammals were recorded in this lateral continuous tuff bed, which we call "T-16" (Figs. 3B, 4 and 8G-H).

Interpretation: Primary tuff beds occurring as sheets lack evidence of erosion at their bases and do not have cross bedding. These deposits derived from settling of volcanic ash (e.g. Cas and Wright, 1987). Thus, each primary tuff of FA11 represents a single event of ash-fall in sub-aerial and subaqueous settings. The presence of in general well preserved, unweathered and, in some cases, partially articulated fossil mammals in these primary tuff deposits, especially in the case of "T-16", attests deposition in floodplain environments (Smith, 1987) (Table 2). In contrast, volcaniclastic facies suggest reworking of ash-fall materials by surface processes and admixture with epiclastic materials (e.g. Smith, 1991; Orton, 1996). The sheet-like shape and the dominance of massive bodies points to unconfined sheet-flood episodes that remobilized pyroclastic materials (Cas and Wright, 1987; Umazano et al., 2012) (Table 2). Incipient paleoedaphic features to the tops of these deposits indicate subaerial exposure, and development of incipient paleosols with very low net sedimentation rates (Smith, 1987), indicating short periods of landscape stability. Humid conditions would have hastened the development of these incipient paleosols.

\subsection{Paleontology}

During three short visits to $\mathrm{RDB}$, mainly devoted to the geological work, some fossil vertebrates were collected. In all, there are 200 taxonomically identifiable specimens, mainly of mammals. As the samples are still in preparation, the real number is unknown. Most of the specimens ( $80 \%)$ were recovered from tuff beds, about 75\% from "T-16" (FA11), and 5\% from the fossil-rich facies Tw (FA2) near the base of the SCF (Fig. 4); the rest were mostly recovered from surface prospecting at various levels between Tw and "T-16", or above the latter. Specimens collected in Tw and "T-16" are in general well preserved, unweathered and, in some cases, partially articulated.

A preliminary faunal list based on our collections is summarized in Appendix 1. This list will be refined and expanded with future preparation and collecting. All the genera and species identified have been previously recorded in the SCF (Marshall et al., 1983; Abello et al., 2012; Bargo et al., 2012; Candela et al., 2012; Cassini et al., 2012; Vizcaíno et al., 2012c). The assemblage is typical of the Early Miocene Santacrucian South American Land Mammal Age (Patterson and Pascual, 1972).

\section{Discussion}

\subsection{Paleoenvironmental reconstruction}

\subsubsection{The transition of the Monte León-Santa Cruz Formation at Rincón del Buque}

Overwhelming evidence indicates that the uppermost part of the MLF as it appears along the Atlantic coast and inland along the eastern parts of Río Santa Cruz was deposited in a tide-dominated shallow marine to estuarine environments (e.g. Bande et al., 2008; Griffin and Parras, 2009; Cuitiño and Scasso, 2008, 2010; Fernicola et al., 2014). Matheos and Raigemborn (2012) also report a fluvialmarine transitional environment in the lowest parts of the coastal SCF.

The evidence reported here further supports the conclusion that the uppermost part of the MLF and the lower part of the SCF at RDB are transitionally fluvial-marine: there was tidal influence as indicated by: 1) mud drapes covering ripples and dune foresets; 2) muddy rip-up clasts; 3 ) hetherolithic intervals composed of interbedded sand, silt and mud; and 4) oposite dipping cross lamination/stratification, and reactivation surfaces. Evidence of wave influence is indicated by symmetrical ripples, and by the reworking of primary pyroclastic materials (soft-sediment deformation structures in IHS facies can be trigged by waves) (Choi et al., 2004; Santos and Rossetti, 2006; Dalrymple and Choi, 2007; Van der Berg et al., 2007; Scasso et al., 2012, among others).

The mixture of land-vertebrate remains with shallow marine invertebrates, leaves of Nothofagaceae and other angiosperm leaves, unidentified carbonaceous remains, blades (common in freshwater fluvial settings), Sphenophytes (characteristic of salt-marshes), and root traces (characteristic of marshes) point to terrestrial and freshwater input from rivers. These are classical features of estuarine environments where small shifts of the coastline leads to rapid changes from shallow marine to terrestrial environments, and/or the organic remains are transported to seaward or landward by alternating tidal currents (Scasso et al., 2012). Also, the coexistence of tidal-influenced deposits with deposits that evidence the action of freshwater is consistent with an estuarine setting.

The ichnological evidence of the uppermost part of the MLF and the lower part of the SCF at RDB supports the above sedimentologybased interpretation. The dominance of brackish water estuarine communities into the analyzed succession is consistent with trace fossil assemblages of low diversity (Buatois et al., 2005; MacEachern and Gingras, 2007). Ichnogenera with a limited saline tolerance are absent but euryhaline marine organisms are present. Trace fossil records indicate the preponderance of trophic generalist organisms, in agreement with modern brackish water communities. Similarly, the relatively small size of trace fossils in relation of their marine counterparts is a brackish-water indicator because ionic and osmotic regulation is difficult in such settings. Nevertheless, as their modern counterparts, Miocene brackishwater deposits do not necessary exhibit size reduction in burrows produced by such crustacean as Thalassinoides, Ophiomorpha and Psilonichnus (e.g. Rosseti, 2000; Gingras et al., 2002; Carmona et al., 


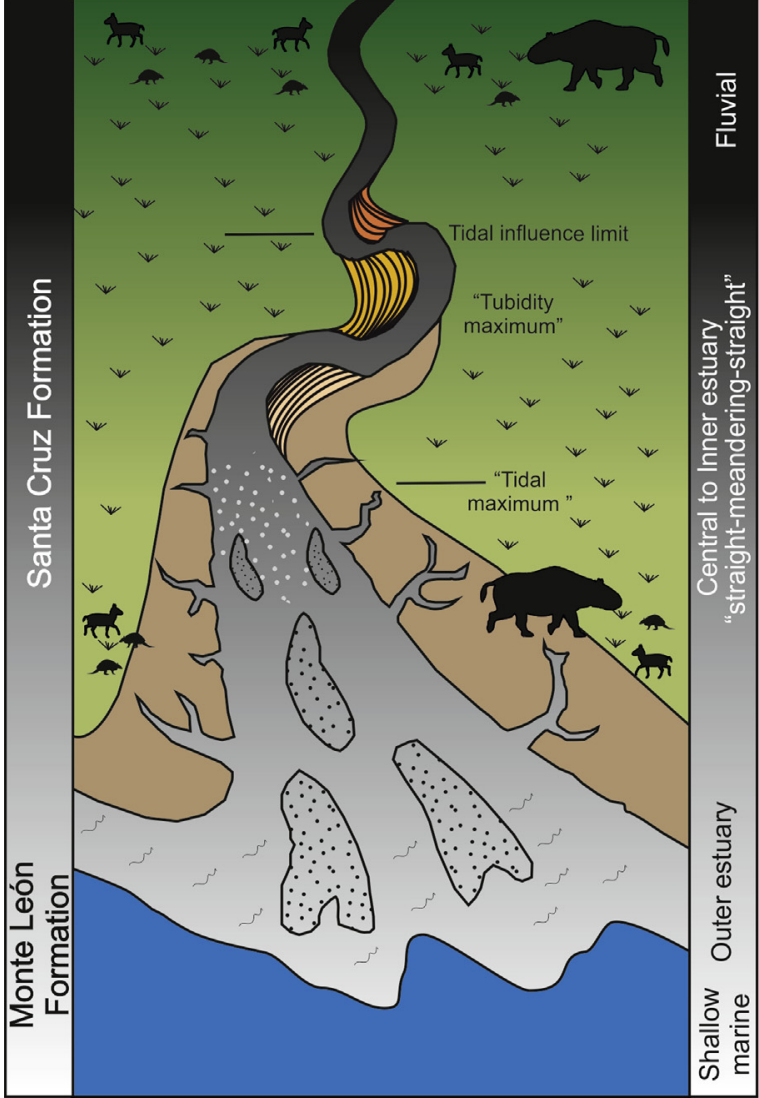

Paleoenvironmental references

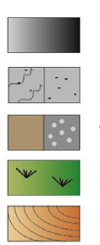

Tidal creeks (FA2) and tidal channels (FA4)

to fluvial channels (FA8)

Subtidal-intertidal deposits (FA1) and longitudinal tidal bars

Tidal flats (FA3) and tidal sand flats (FA5)

Marshes (FA6) to fluvial floodplains (FA10 and FA11)

Tidal-fluvial point bars (FA7) to fluvial point bars (FA9)

\section{Paleontological references}

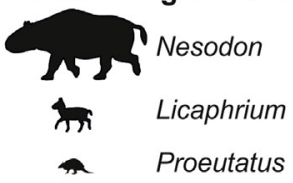

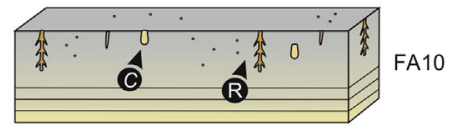
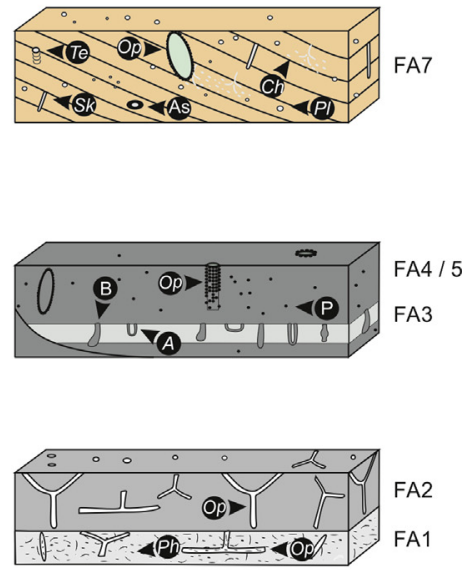

Ichnological references

Ph: c.f. Phycosiphon

Op: Ophiomorpha isp.

A: Arenicolites isp.

$\mathrm{P}$ : Fecal pellets

$B$ : Vertical dwelling structures

of stationary location of bivalves

As: Asterosoma isp.

$\mathrm{Pl}$ : Planolites montanus

Sk: Skolitos isp.

Ch: Chondrites isp.

Te: Teichichynus rectus

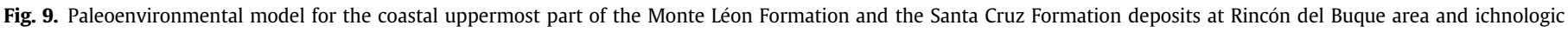
assemblages. The schematic tide-dominated estuary is modified from Darlrymple and Choi (2007) and Scasso et al. (2012).

2009). Crustacean dwelling structures at RDB (Ophiomorpha isp.) agree with other Miocene recorded cases in having only a small reduction in size (e.g. Carmona et al., 2008). In brackish water environments, salinity fluctuations mostly affect the water column, but a few centimeters into the substrate, the sediment is barely affected because the presence of impermeable fine sediments slows down the exchange of pore water allowing it to be inhabited by a wider variety of endobenthic organism. This results in the dominance of vertical subsurface trace fossils produced by infaunal organisms rather than surface epifaunal trails.

Brackish water conditions are also suggested by the occurrence of monospecific accumulation of $C$. orbignyi, a brackish water tolerant organism (Griffin and Parras, 2012; Cuitiño et al., 2013), in the top of the MLF (FA1). Stressed conditions due to dilution of normal marine waters take place in a setting where freshwater discharge contributes. Brackish water ichnofaunas and a brackish water tolerant $C$. orbignyi also attest an estuarine environment for the uppermost MLF.

The transition of the MLF-SCF at RDB area reflects a changing depositional environment (Figs. 4 and 9). Volcaniclastic deposits at the base of the profile at RDB-N (FA1) record a Skolithos-Cruziana ichnofacies (TFA1) with higher BI suggesting minor periods of salinity fluctuation due to fresh water input. Consequently, FA1 of the uppermost MLF possibly represent the subtidal-intertidal deposits of the outer estuary (Figs. 4 and 9). The vertical relationship of the FA1 (MLF) with the overlying mammal-rich reworked pyroclastic deposits (FA2; SCF) of a freshwater and continental origin suggests that the most basal levels of SCF was deposited very close to the coastline. This FA is interpreted as tidal creeks that scour tidal flats and marshes (FA3 and FA6, respectively) in the central part of 

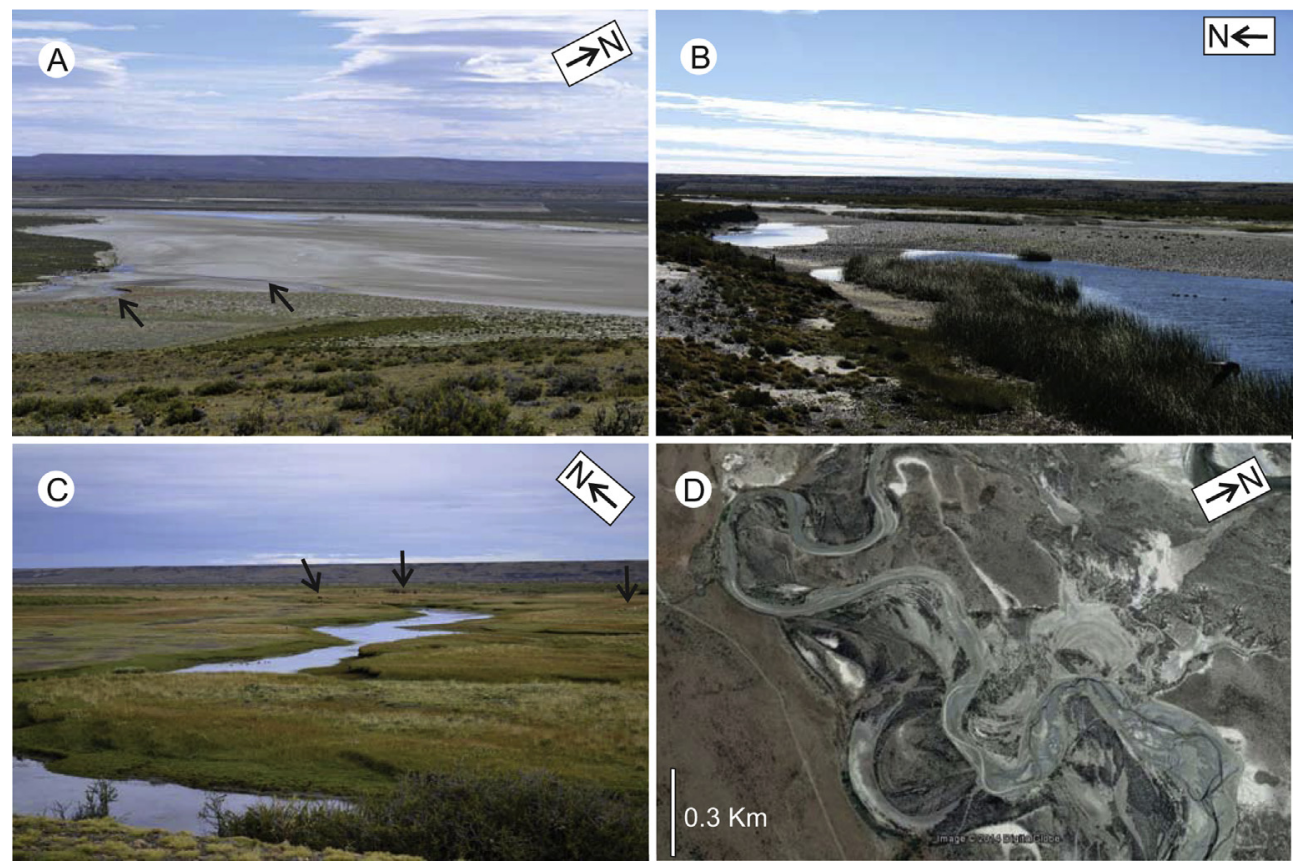

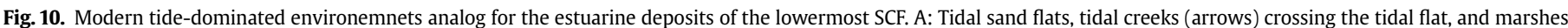

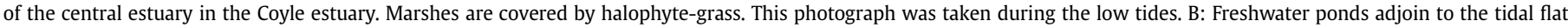

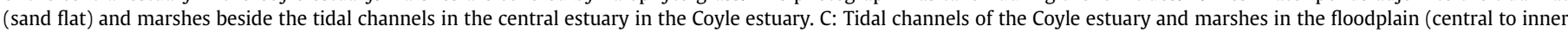

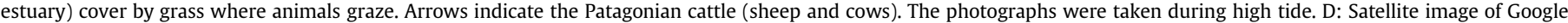
Earth showing meandering tidal channels and tidal point bars developed in the meandering area (inner estuary) of the Coyle estuary.

an estuary (Figs. 4 and 9). The taphonomic features of the vertebrate fossils of the FA2 suggest that the remains were transported only for short distances or not at all. Therefore, the terrestrial fossils probably correspond to animals that inhabited freshwater areas where ponds and marshes adjoin to the tidal flats and channels (Fig. 9). Similarly, Brea et al. (2012) point out that the features of the preserved leaves at RDB-S locality, within the TS facies (FA2), suggest that transportation of the leaves could only have been over a short distances from their source, up to a few kilometres, or dispersed short distances by wind. Thus, it is probably that fossil leaves suggest that the coastal region was forested, as was also suggested from palynological records by Barreda and Palazzesi (2007). The occurrence of Ophiomorpha isp. burrows (TFA2) within the mammal-rich Tw facies of FA2 is distinct from purely freshwater fluvial channels of the FA8. However, the mix of leaf debris, fossil mammals, and marine fossil traces of low diversity suggest that channels of the FA2 were periodically influenced by fluvial discharge.

This basal succession of the SCF is succeeded by infills of sandy tidal channels (FA4) developed in the central part of an estuary (Figs. 4 and 9). The presence of mud clast within these channels indicates deposition in the vicinity of the "turbidity maximum" (Fig. 9). Paleocurrent directions were predominantly east-southeast with a smaller component running south-southwest with largescale subaqueous dunes migrating in the same directions as the current. Similarly, the FA5 represent tidal sand flats of the central estuary, in a seaward position respect to the tidal channel deposits, and located beneath the peak of the "turbidity maximum" and near to the "tidal maximum" (Fig. 9). All these sandy facies tend to lack biogenic structures, excepting for monospecific suites of Ophiomorpha isp. (TFA4) in soft ground indicating an impoverish Skolithos ichnofacies in brackish conditions.

Sandy deposits of tidal channels (FA4) and tidal sand flats (FA5) are laterally and vertically associated with tidal flats (FA3), salt marsh (FA6) and tidal-fluvial point bars (FA7); these are deposits of the central and inner parts of an estuary (Fig. 9). Sandy-muddy facies in hetherolithic intervals of the FA3, are interpreted as tidal flat deposits closely associated with tidal sand flats deposits (FA5) (Fig. 9). Some colonization of firm ground substrates by bivalves and polichaetes (TFA3) is observed within this facies indicating pauses in deposition (e.g. Pearson et al., 2012). The tracemaking organisms initially colonized muds that had been exhumed by erosion; subsequently the traces were passively infilled. These correspond to autogenic examples of the Glossifungites ichnofacies denoting minor erosional surfaces within the tidal flat. The colonization of autogenic firmgrounds implies significantly shorter time of exposure after exhumation than in allogenic firmgrounds that have a basinwide scale (Pearson et al. 2012).

IHS facies of the FA7, recorded only at RDB-S, represent tidalfluvial point bars. Seaward-dipping IHS present in the northnortheast represents deposition beneath the "turbidity maximum" in the central to inner estuary (Fig. 9). IHS facies record a depauperate mixture of both the Skolithos and Cruziana ichnofacies (TFA5), the alternation corresponding to fluctuations in energy inputs typical of estuarine environments, but also influenced by the abundant nutrient availability in the water column and the substrate (MacEachern and Gingras, 2007). The abundance of simple structures of trophic generalists is possibly related to these rich food resources. Upward in the succession a gradual transition to the fluvial environment (FA8-11) occurred (Figs. 4 and 9).

Modern day analogs for the depositional environment of the lowermost part of the coastal SCF can be found in several estuaries of the Patagonia region on the southeastern Atlantic coast as those of the Río Santa Cruz, Río Coyle, and Río Gallegos, each of which opens directly to the South Atlantic. For instance, the Coyle estuary (Fig. 10) is hypertidal with less extensive longitudinal bars near the sea in the outer estuary, whilst being dominated by extensive tidal sand flats in the central estuary (Figs. 10A and B) and fluvio esturine 


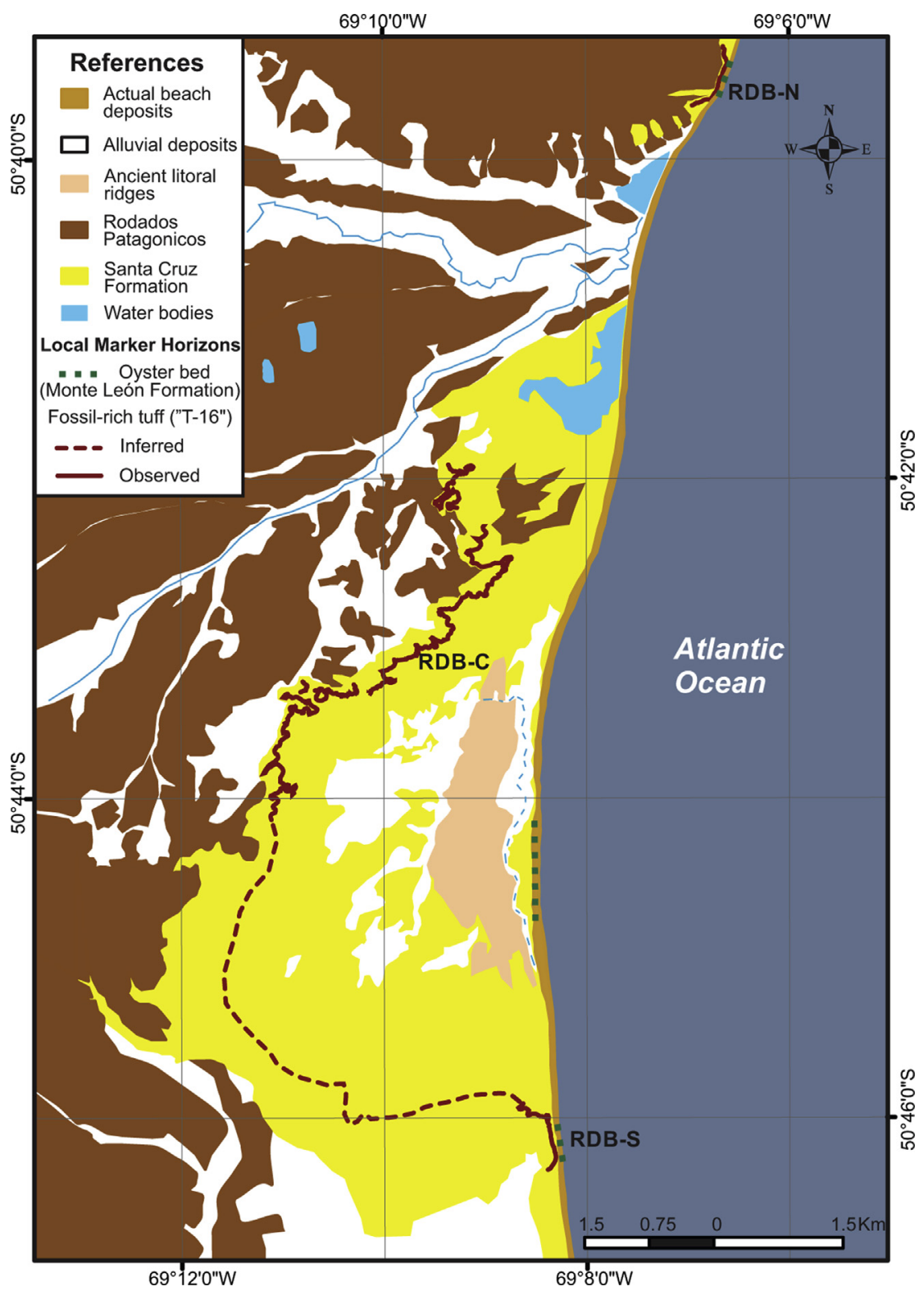

Fig. 11. Geological map of the study area showing position and distribution of the main marker horizons.

channels with large fluvio-estuarine point bars in the inner estuary (Figs. 10C and D) (Archer, 2013). In addition these modern Patagonian estuaries also resemble those of the Early Miocene in that there is influence of the Andean volcanic activity, for example with volcanic ash being deposited on the tidal sand flats (Archer, 2013). However, unlike the Early Miocene estuary that developed in an actively subsiding basin and with large river systems that fed a coastal zone prograding seaward, the Coyle estuary has minimum fluvial connection with limited/absence of freshwater flux that may allow an influx of marine-derived sediments (Archer, 2013), and it is characterized as a flooded river valley (Piccolo and Perillo, 1999) developed in an erosion dominated region.

\subsubsection{The middle and upper section of the Santa Cruz formation at Rincón del Buque}

At RDB, continental influence comes to dominate upsection. The transition from FA1-7 (estuarine deposits) to FA8-11 (fluvial deposits) can be recognized in the shifting lithofacies, the fossil content, and the shapes of the beds distinguishing estuarine (tidal channels/ creeks, tidal sand flats, tidal point bars and tidal flat/marshes) from riverine conditions (fluvial channels, fluvial bars and fluvial floodplain). The overall decrease in marine influence is evidenced by the decline in marine fossils and their traces. Paleoedaphic features and exclusively remains of continental vertebrates as well as leaf compressions appear as tidal influences disappear (Fig. 4).

FA8-11 are interpreted as being produced by a fluvial system with single channels of relatively low energy and low sinuosity (FA8) similar to those described by Matheos and Raigemborn (2012), enclosed in a broad floodplain dominated by sheet-flood, overbank and ash-fall deposits (FA10 and FA11). Large-scale cross bedding of the FA9 indicating the presence of sinuosity in the fluvial system is seen exclusively in the middle part of the analyzed RDB-S section (Figs. 3C and 4) superimposed upon inner estuary deposits without cross-bedding. The lack of marine trace fossils and the presence of continental remains (leaves and blades) at RDB-S signifies a fluvial-dominated depositional regime. Such deposits 
represent fluvial point bars (e.g. Johnson and Dashgard, 2014), probably positioned in the fluvially dominated setting of the transitional tidal-to-fluvial part of the estuary (Fig. 9). Fine-grained fluvial point bars or counter point bars are characteristic of the lowermost reaches of low-energy meandering rivers in tidal estuaries (Fig. 9) (e.g. Smith et al., 2009).

\subsubsection{Pyroclastic and volcaniclastic sedimentation at Rincón del Buque}

Ash-fall deposits ( $\mathrm{T}$ facies), reworked tuffs (Tw facies), and tuffaceous sandstones (TS facies) of both MLF and SCF attest to a supply of sub-aerial eruptions from an active volcanic source area. Moreover, the decrease of pyroclastic deposits up section of the analyzed SCF at RDB (Fig. 4) probably indicates a diminution in explosive volcanic activity. The tabular shape and the lateral extension of the primary tuff as the "T-16" level, in the study area suggest that pyroclastic materials mantled a flat paleosurface. The relatively fine grain size of the primary tuff in the study area must have been deposited as ash-falls that affected the Austral basin as a whole. Reworked tuffs of the middle and upper sections of the analyzed SCF (Fig. 4) reveal a fluvial environment influenced by an active volcanic source area where a large amount of fine-grained pyroclastic particles were mixed with epiclastic particles. Similarly, reworked tuff and tuffaceous sandstones of the uppermost MLF and the lower part of the SCF at RDB (Fig. 4) indicate pyroclastic materials, which reached the marginal estuarine environment by freshwater input and then were reworked and mixed with other materials (e.g. Cuitiño and Scasso, 2013). Subsequently these materials were bioturbated by marine organisms. The presence of carbonaceous material, leaves, and mammal bones in pyroclastic and volcaniclastic facies reinforce the interpretation that the pyroclastic material was supplied from the land. In the same way, the salinity-stressed conditions suggested by fossil traces are related to fluvial input into the coastal system. An additional source of stress, together with the elevated sedimentation rates during explosive volcanism, may be due to the acidification of the flowing waters interacting with volcanic particles (Cuitiño and Scasso, 2013). The alternation of ash-fall deposits with reworked tuffs and nonpyroclastic deposits through the succession suggests episodic sedimentation in which the volcanic influence was important. Major sedimentation would have taken place during episodes of intense volcanism (syn-eruptive periods); when volcanism decreased or ceased (inter-eruptive period), erosion and reworking dominate the system (Smith, 1991).

The initial influx of volcaniclastic sediments in the coastal Atlantic region began at $\sim 22 \mathrm{Ma}$ (age of the base of the coastal pyroclastic-rich MLF; Parras et al., 2012) and continued uninterrupted until at least $16 \mathrm{Ma}$, the age of the youngest strata of the SCF in the Atlantic coastal plain. However, in the Andean foothill it occurred somewhat earlier at $\sim 19 \mathrm{Ma}$, and finished at $\sim 14 \mathrm{Ma}$ (Blisniuk et al., 2005; Fleagle et al., 2012; Perkins et al., 2012). The mentioned oldest ages represent the beginning of the continental synorogenic sedimentation immediately after the eastward withdrawal of the "Patagonian" sea, which westward started one million years earlier (Cuitiño et al., 2012; Bostelmann et al., 2013). The source area of these pyroclastic materials probably was located $\sim 300-400 \mathrm{~km}$ to the west in the Andean range (Matheos and Raigemborn, 2012; Cuitiño and Scasso, 2013), where the South Patagonian Batholith is currently located (Fig. 1A) (Hervé et al., 2007). This is a similar setting as now occurs in the dispersal of ash deriving from highly explosive eruptions in the southernmost Southern Volcanic Zone and Austral Volcanic Zone of the Andean Range hundreds of kilometres from the source (Ramos and Kay, 1992) where ash is distributed east and south-eastward over Austral Patagonia (e.g. Hudson eruptions in the last $\sim 10.000$ years [see Stern, 1991; Scasso et al., 1994]; the eruptions of the Lautaro and Viedma volcanoes in the past two centuries [see Martinic, 2008 http://www.segemar.gov.ar/]) (see position of these volcanoes in Fig. $1 \mathrm{~A}$ ), and the recent eruptions of the Chaitén and Puyehue volcanoes (e.g. Lara, 2009; Mulena et al., 2012).

Vertebrate bones in tuff beds Tw and "T-16", although deposited in different environments (one estuarine and another continental), each show very little reworking indicating short or no transport before deposition, and rapid burial without exhumation (e.g. de Valais et al., 2012; Rogers and Kidwell, 2000). Considering that volcanic activity causes high mortality rates (e.g. Guo et al., 2007) and that sedimentation rates were high $(100-200 \mathrm{~m} / \mathrm{Ma}$ on average; Perkins et al., 2012) for the SCF (see below), specially during ash-bed deposition where sedimentation rate is instantaneous, it is probable that the vertebrate remains represent a community living very close to the setting of accumulation (in the tidal flat or marshes for Tw of the FA2, and in the floodplain for "T-16" of the FA11). Similar catastrophic ash-fall events from Miocene Andean volcanism account for the death and entombment of crabs were registered in the MLF (Crawford et al., 2008).

\subsubsection{Paleoclimatic reconstruction at Rincón del Buque}

Several taxa recovered south of Río Coyle in penecontemporaneous levels to those of RDB (e.g. palm trees, the frog Calyptocephalella, the lizard Tupinambis, the anteater Protamandua, and the primate Homunculus) strongly indicate that the climate was much warmer and wetter than today. The overall mammalian species richness and niche composition, expressed as percentages of arboreal or scansorial, frugivorous, and grazing species, suggest that overall rainfall was in the range of $1000-1500 \mathrm{~mm}$ per annum (Kay et al., 2012b) just to the south of RDB. Similarly, the occurrence at RDB of trees and forest-dwelling birds and mammals (spiny rats, sloths and scansorial marsupials) supports this conclusion. Although the fauna recorded in RDB so far does not allow the same specificity, what we know so far is consistent with the same paleoclimatic and paleoecologic interpretation. Based on plant macro- and microfossils, the vegetation of the lower part of the SCF section indicates estuarine and fluvial environments with the ground covered by warm-temperate semi-arid to humid forests, with seasonally low precipitation limiting for plant growth (Brea et al., 2012). Isotopic data of $C$. orbignyi from the top of the MLF at southwestern Patagonia suggest the presence of warm oceanic currents affecting the Early Miocene Patagonia shelf (Cuitiño et al., 2013).

Evidence of seasonal climatic conditions came also from the sedimentological and ichnological features. For example, the occurrence of cells of solitary bees (Celliforma isp.) and the presence of pedogenic carbonate (carbonate concretions) in well-drained paleosols suggest drier climatic condicions, meanwhile the alternation of waterlogged-paleosols and well-drained paleosols throughout the middle-upper section of the analyzed succession, indicate a certain degree of seasonality.

\subsection{Correlation and age of the Rincón del Buque vertebrate fossil levels with previously described Santacrucian localities}

The oyster bed of the uppermost part of the MLF (Sb; FA1) which demarcates the top of the MLF, is recognized in the sections of RDB$\mathrm{N}$ and RDB-S (Fig. 3A, C and 4), and also at the base of the middle sector of RDB area (Fig. 11), making it a good local marker horizon in the study area. Likewise, several representative tuff beds are also useful guide beds in the study area (Fig. 4), such as, ribbon-like bodies of reworked tuffs (Tw; FA2), belong to the lowermost part of the analyzed SCF above the oyster bed where the fossil mammals take place, and sheet-like bodies of reworked tuffs (Tw; FA6). Finally, tuff "T-16" (T; FA11) is exposed in all sections within the 
study area and makes another good marker horizon (Fig. 4). Thus, the three stratigraphic marker horizons allow us to establish correlations within the RDB area. The areal distributions of these guide horizons are shown in Fig. 11.

As mentioned above, using a relatively inaccurate $\mathrm{K}-\mathrm{Ar}$ method, Marshall et al. (1986) reported a date of $\sim 16 \pm 0.8$ Ma for a tuffaceous sample that came from the NE side of the amphitheater of RDB area, about $20 \mathrm{~m}$ above the base of the outcrops. Earlier, Bordas (1941) mentioned a fossiliferous tuff $35 \mathrm{~m}$ above the oyster bed of the Superpatagoniense. Our "T-16" level is located between 32 and $\sim 41 \mathrm{~m}$ above the last oyster bed of the MLF (Fig. 4). Considering that "T-16" is the most conspicuous mammal-rich tuff level, in the absence of other information we propose that Bordas' and Marshall's tuffs are equivalent to our "T-16".

South of RDB Santacrucian coastal localities occur along the $70 \mathrm{~km}$ beach strand from the inlet of Río Coyle south to the inlet of Río Gallegos (Figs. 1A and B). These southern localities were interpreted by Tauber $(1994,1997 a)$ as a stratigraphic succession on account of an estimated regional $3^{\circ}$ average dip to the southeast of the SCF. Three tuff horizons that crop out to the top of the exposures in Cañadón del Indio (Fig. 1B) were used by Tauber (1994, 1997a) and Kay et al. (2008) as levels to establish correlations among the localities between Cañadon del Indio and Puesto Estancia La Costa (Fig. 1B). Perkins' et al. (2012) work with tephrostratigraphy suggest that localities between Estancia La Costa and Puesto Estancia La Costa (including Cañadon Silva) (Fig. 1B), are more horizontally disposed and penecontemporaneous. Tauber and later Kay et al. (2008), suggest that the fossiliferous localitites south of Puesto Estancia La Costa (including Cabo Buen Tiempo, Cañadón Las Totoras and Monte Tigre) (Fig. 1B) are younger than the northerly localities, owing to the SE regional dip, a finding confirmed by the work of Perkins et al. (2012).

North of RDB at Monte León, where the contact MLF-SCF is observed, and at Cerro Observatorio-Cañadón de las Vacas (Fig. 1A), a sequence of tuffaceous horizons that crops out low in the section ( $20 \mathrm{~m}$ from the base) had been dated at $16.3 \mathrm{Ma}$ (Fleagle et al., 1995). This sequence was correlated with the marker horizons of Cañadón del Indio by Kay et al. (2008). More recently, Perkins et al. (2012) and Fleagle et al. (2012) showed an updated scheme of correlation between southern Río Coyle and Cerro Observatorio-Monte León National Park areas (Fig. 12). An interval of closely spaced tuffs near to the base of the SCF was designated by Perkins et al. (2012) as "L1-3". The base of this interval, just below the last oyster bed, was dated at 17.7 Ma ("PAT" tuff). The top of "L1-3" was dated on 17.4 Ma ("CO" tuff) (see Fig. 2.2 of Perkins et al., 2012; and Fig. 12). The L1-3 interval includes the three tephra of Cañadón del Indio (" $<\mathrm{CI}, \mathrm{CI}$ and $\mathrm{CO}$ " tuffs).

Tentatively then, the RDB composite section overlaps the lower part of the southern region (Cañadon del Indio to Puesto Estancia La Costa and the middle part of the section at Monte León) (Fig. 1A) it is plausible to correlate the oyster bed and the tuffaceous levels of RDB with the previously described localities. Considering that the "L1-3" interval begin with a tuff level ("PAT") close to the last oyster bed, this could be represented in our area, at least in RDB-N and RDB-S (Fig. 4), by the lower tuff levels immediately above the oyster bed. Upsection, the fossil-rich tuff "T-16" could be correlated with the "CO" of Cañadón del Indio. As we understand it, the "L1-3" interval ( 17.7-17.4 Ma) is recorded in the basal $30 \mathrm{~m}$ of the SCF at RDB area (Fig. 12), which represents an accumulation rate of $\sim 100 \mathrm{~m} / \mathrm{Ma}$. This high sedimentation rate is consistent with the low degree of bioturbation (BI variable between 0 and 3 ) in the lower section of the analyzed SCF (estuarine deposits) and with other indicators of a high sedimentation rate such as the preservation of thick packages of floodplain deposits, the isolation and the low connectivity of the channels upsection, and the immaturity of the paleosols. Cuitiño et al. (2012) mentioned high sedimentation rates $(\sim 170 \mathrm{~m} / \mathrm{Ma})$ for the upper member of the Estancia 25 de Mayo Formation ( $=\mathrm{MLF}$ ) in the Andean region of the Santa Cruz Province. Similarly, high sedimentation rates (100-200 m/Ma on average) were estimated by Perkins et al. (2012) based on radiometric age determinations for the coastal SCF.

Although the SCF at RDB is fossiliferous throughout, the richest and best-preserved specimens so far come from "T-16". On present evidence, "T-16" correlates with to the "L1-3" interval south of Río Coyle in the lower part of the coastal SCF (Fleagle et al., 2012; Perkins et al., 2012), and the section as a whole is equivalent to Estancia La Costa Member. Therefore, RDB is broadly correlated with the Santacrucian localities of Estancia La Costa, Cañadon Silva and Puesto Estancia La Costa, south of Río Coyle (Fig. 1B) (Kay et al., 2008; Vizcaíno et al., 2010). Furthermore, based on the proposed correlations (Fig. 12), it is probable that the RDB's fauna are slightly younger than the Anfiteatro-Campo Barranca's fauna (Fig. 1B) due to the fact that the fossil-rich tuffs of these localities are correlated with " $<\mathrm{CI}$ and $\mathrm{Cl}$ " tuffs, whereas the mammalbearing tuff of RDB would correlate with the overlying "CO" tephra (Fig. 12).

To the north, the correlation between "T-16" and localities in Cerro Observatorio-Cañadón de la Vacas and Monte León National Park (Figs. 1A and 12) would indicate that the first is contemporary with the fossil-rich level of the Stake (staca) \#64 of the Cerro ObservatorioCañadón de las Vacas described by Bown and Fleagle (1993).

\section{Conclusions}

The uppermost levels of the Monte León Formation (MLF) and the deposits of lower part of the Santa Cruz Formation (SCF), both of Early Miocene age, crop out along the Atlantic coastline of the Santa Cruz Province in the Rincón del Buque area (north to Río Coyle; Patagonian Argentina) as a conformable succession rich in

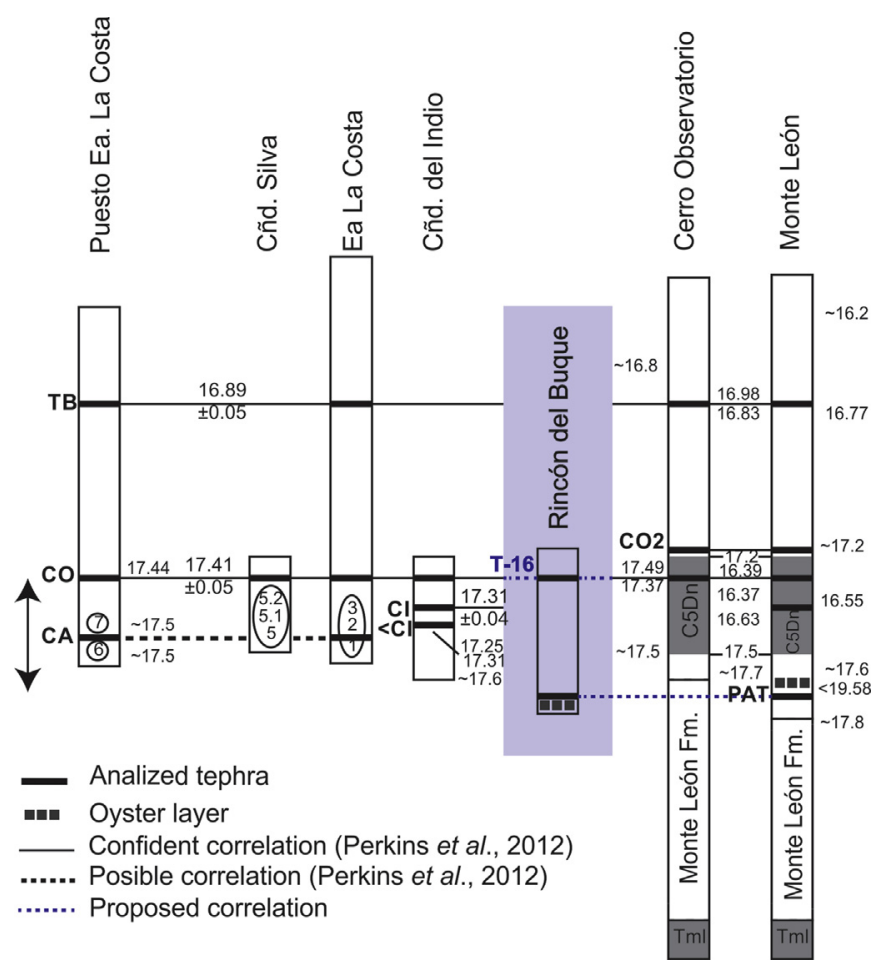

Fig. 12. Correlation diagram between Rincón del Buque and other coastal Santacrucian localities. Modified from Fleagle et al. (2012) and Perkins et al. (2012). 
terrestrial vertebrate fossils and marine trace fossils. The sedimentological, ichnological and paleontological analysis of the succession shows that the settings of deposition vary from estuarine to fluvial, and attest a progradation with continentalization upsection. The uppermost levels of the MLF and the lowermost beds of the SCF contain subtidal to intertidal deposits with $C$. orbignyi specimens and bioturbation of the Skolithos-Cruziana ichnofacies (FA1), tidal creek deposits with terrestrial fossil mammal remains and Ophiomorpha isp. burrows (FA2), and tidal flat deposits with Glossifungites ichnofacies (FA3). These three facies associations represent the more seaward part of an estuary (outer and central estuary). Upsection, the levels of the SCF represent the infill of tidal channels (FA4) and tidal sand flat deposits (FA5) with associated impoverished Skolithos ichnofacies, marsh deposits (FA6), and tidal pointbar deposits (FA7) recording a depauperate mixture of both the Skolithos and Cruziana ichnofacies. This interval of the SCF was deposited in the central and inner parts of a tide-dominated estuary. These tide-influenced deposits are transitionally covered by continental facies of fluvial channels deposits (FA8), fluvial point bars deposits (FA9), and edaphized, bioturbated and mammal-rich floodplain deposits (FA10 and FA11), which represent a low energy and low sinuosity fluvial system.

Pyroclastic and volcaniclastic materials are present in the analysed succession sourced by sub-aerial eruptions from an active volcanic source area located in the Andean range that affected the Austral Basin. These materials must have been deposited as subaerial distal facies in a fluvial setting and also were carried by fluvial streams and redeposited in both estuarine and fluvial settings. Volcanic materials preserve most of the terrestrial fossil mammals distinctive of the Santacrucian Land Mammal age of the RDB succession.

The alternation of pyroclastic material with volcaniclastic and epiclastic material throughout the RDB area suggests episodic sedimentation with volcanic influence, and could represent the alternation of syn-eruptive and inter-eruptive periods, respectively. In addition, high sedimentation rates are assumed for the analyzed section of the SCF on the basis of the low degree of marine bioturbation (BI 0-3), the preservation of thick packages of floodplain deposits, the isolation and low connectivity of channel deposits upsection, the immaturity of the paleosols, and for the interpreted geochronological data that indicate an accumulation rate of $\sim 100 \mathrm{~m} / \mathrm{Ma}$, on average, for the basal $30 \mathrm{~m}$ of the SCF at RDB area.

Paleoclimatic inferences from sedimentological, paleontological and ichnological analyses indicate a relatively warm and seasonal climate for the Early Miocene in the coastal area of the Santa Cruz Province, in agreement with previous paleoclimate reconstructions.

The wide lateral extension of both the oyster-rich bed demarcating the top of the MLF, and the tuffaceous levels of SCF especially the highly fossiliferous "T-16" tuff level, are useful stratigraphic marker horizons for correlation with other fossil-bearing localities. We correlate the basal $30 \mathrm{~m}$ of the SCF at RDB area with the lower part of the coastal SCF south of Río Coyle -Estancia La Costa, Cañadon Silva and Puesto Estancia La Costa- ( 17.7-17.4 Ma), equivalent to the Estancia La Costa Member. Moreover, the RDB's principal faunal level is slightly younger than the Anfiteatro-Campo Barranca's fauna.

\section{Acknowledgements}

The authors are very grateful to Ari Iglesias (CONICET) for the paleobotanical analysis; Nahuel Muñoz (Museo de La Plata), Jerónimo Zuazo (UNLP) and Rodrigo García (Coy Aike Farm) for field assistance; J. Noriega (CCYTPP-Diamante) for the identification of bird specimens, and M. Arnal, A. Abello, N. Muñoz, N. Toledo (Museo de La Plata) and S. Hernández del Pino (IANIGLA-Mendoza) for identification of mammals. The suggestions made by Dr. José I. Cuitiño and an anonymous reviewer greatly improved the quality of this manuscript.

Financial and logistical support for field studies was provided by the projects PIP- CONICET 00066 and 00191 and UNLP N680 to SDM, and PICT 0143 and UNLP N647 to SFV. Support for the fieldwork also derives from National Science Foundation grant BNS0851272 to RFK.

\section{Appendix 1. Preliminary faunal list of Rincón del Buque locality.}

\author{
MARSUPIALIA \\ Paucituberculata \\ Caenolestidae indet. \\ Palaeothentidae \\ Palaeothentes intermedius \\ Palaeothentes lemoinei \\ Palaeothentes minutus \\ Palaeothentes cf. aratae \\ Acdestis lemairei \\ Acdestis owenii \\ Microbiotheriidae \\ Microbiotherium tehuelchum \\ Sparassodonta \\ Hathlyacynidae indet.
}

\author{
XENARTHRA \\ Cingulata \\ Peltephilidae \\ Peltephilus \\ Dasypodidae \\ Proeutatus \\ Prozaedyus \\ Stenotatus \\ Propalaehoplophoridae \\ Cochlops \\ Pilosa \\ Megatherioidea \\ cf. Pelecyodon
cf. Hapalops
}

Propalaehoplophoridae indet

\author{
RODENTIA \\ Chinchilloidea \\ Neoepiblemidae \\ Dinomyidae \\ Cavioidea \\ "Eocardiidae" \\ Phanomys sp
}

Perimys sp

cf. Scleromys 


\section{"Eocardia"sp \\ Dasyproctidae \\ Neoreomys sp \\ Octodontoidea \\ Acarechimys minutus \\ Acarechimys minutissimus \\ Spaniomys sp \\ Spaniomys riparius \\ Acaremyidae \\ Acaremys $s p$ \\ Sciamys principalis}

\section{NOTOUNGULATA \\ Toxodontia \\ Toxodontidae \\ Nesodon \\ Adinotherium \\ Homalodotheriidae \\ Homalodotherium \\ Typotheria \\ Interatheriidae \\ Interatherium \\ Protypotherium \\ Hegetotheriidae \\ Hegetotherium}

\section{LITOPTERNA \\ Proterotheriidae \\ Tetramerorhinus \\ cf. Diadiaphorus \\ Macraucheniidae \\ Theosodon}

\section{ASTRAPOTHERIA \\ Astrapotheriidae \\ Astrapotherium}

\section{References}

Abello, M.A., Ortiz-Jaureguizar, E., Candela, A.M., 2012. Paleoecology of the Paucituberculata and Microbiotheria (Mammalia, Marsupalia) from the late Early Miocene of Patagonia. In: Vizcaíno, S.F., Kay, R.F., Bargo, M.S. (Eds.), Early Miocene Paleobiology in Patagonia: High-latitude Paleocommunities of the Santa Cruz Formation. Cambridge University Press, Cambridge, pp. 156-172.

Ameghino, F., 1902. Notices préliminaires sur des mammifères nouveaux des terrains crétacés de Patagonie. Boletín Acad. Nac. Ciencias 17, 5-70.

Ameghino, F., 1906. Les formations sédimentaires du Crétacé Supérieur et du Tertiaire de Patagonie avec un parallelé entre leurs faunes mammalogiques et celles de l'ancien continent. An. del Mus. Nac. Buenos Aires 8, 1-568.

Arbe, H.A., 1987. El Cretácico de la Cuenca Austral. Boletín Inf. Pet. 9, 91-110.

Archer, A.W., 2013. World's highest tides: hypertidal coastal systems in North America, South America and Europe. Sediment. Geol. 284-285, 1-25.

Bande, A., Scasso, R., Porfiri, G., 2008. Análisis paleoambiental de las formaciones Patagonia y Santa Cruz, en la zona del lago Posadas, provincia de Santa Cruz. In: XII Reunión Argentina de Sedimentología, vol. 37.

Bargo, M.S., Toledo, N., Vizcaíno, S.F., 2012. Paleobiology of the Santacrucian sloths and anteaters (Xenarthra, Pilosa). In: Vizcaíno, S.F., Kay, R.F., Bargo, M.S. (Eds.) Early Miocene Paleobiology in Patagonia: High-latitude Paleocommunities of the Santa Cruz Formation. Cambridge University Press, Cambridge, pp. 216-242.

Barreda, V.D., Palamarczuk, S., 2000. Palinomorfos continentales y marinos de la Formación Monte León en su área tipo, provincia de Santa Cruz, Argentina. Ameghiniana 37, 3-12.

Barreda, V.D., Palazzesi, L., 2007. Patagonian vegetation turnover during the Paleogene-Early Noegene: origin of arid-adapted floras. Bot. Rev. 73, 31-50.

Bertels, A., 1970. Sobre el "Piso Patagoniano" y la representación de la época del Oligoceno en Patagonia Austral, República Argentina. Rev. la Asoc. Geol. Argent. $25,496-501$.

Biddle, K.T., Uliana, M.A., Mitchum Jr., R.M., Fitzgerald, M.G., Wright, R.C., 1986. The stratigraphic and structural evolution of the central and Eastern Magallanes
Basin, southern South America. In: Allen, P.A., Homewood, P. (Eds.), Foreland Basins. International Association of Sedimentologists, vol. 8. Special Publication, Blackwell, pp. 41-61.

Blisniuk, P.M., Stern, L.A., Chamberlain, C.P., Idleman, B., Zeitler, K.P., 2005. Climatic and ecologic changes during Miocene surface uplift in the Southern Patagonian Andes, Earth Planet. Sci. Lett. 230, 125-142.

Bordas, A.F., 1941. Restos fósiles de Rincón del Buque. Physis 19, 55-61.

Bostelmann, J.E., Le Roux, J.P., Vásquez, A., Gutiérrez, N.M., Oyarzún, J.L., Carreño, C., Torres, T., Otero, R., Llanos, A., Fanning, C.M., Hervé, F., 2013. Burdigalian deposits of the Santa Cruz Formation in the Sierra Baguales, Austral (Magallanes) Basin: age, depositional environment and vertebrate fossils. Andean Geol. 40, 458-489.

Bown, T.M., Fleagle, J.G., 1993. Systematics, biostratigraphy, and dental evolution of the Palaeothentidae, later Oligocene to early-middle Miocene (Deseadan-Santacrucian) caenolestoid marsupials of South America. J. Paleontol. 67, 1-76.

Brea, M., Zucol, A., Iglesias, A., 2012. Fossil plant studies from late Early Miocene of the Santa Cruz Formation: paleoecology and paleoclimatology at the passive margin of Patagonia, Argentina. In: Vizcaíno, S.F., Kay, R.F., Bargo, M.S. (Eds.), Early Miocene Paleobiology in Patagonia: High-latitude Paleocommunities of the Santa Cruz Formation. Cambridge University Press, Cambridge, pp. 104-128.

Bridge, J., 2003. Rivers and Floodplains, first ed. Blackwell Science, p. 491.

Buatois, L.A., Gingras, M., Maceachern, J.A., Mángano, M.G., Zonneveld, J.P., Pemberton, S.G., Netto, R.G., Martin, A., 2005. Colonization of brackish-water systems through time: evidence from the trace fossil record. Palaios 20, $321-347$.

Candela, A.M., Rasia, L.L., Pérez, M.E., 2012. Paleobiology of Santacrucian caviomorph rodents: a morphofunctional approach. In: Vizcaíno, S.F., Kay, R.F., Bargo, M.S. (Eds.), Early Miocene Paleobiology in Patagonia: High-latitude Paleocommunities of the Santa Cruz Formation. Cambridge University Press, Cambridge, pp. 287-305.

Carmona, N.B., Buatois, L.A., Mángano, M.G., Bromley, R.G., 2008. Ichnology of the Lower Miocene Chenque Formation, patagonia, Argentina: animal-substrate interactions and the modern evolutionary fauna. Ameghiniana 45, 93-122.

Carmona, N.B., Buatois, L.A., Ponce, J.J., Mángano, M.G., 2009. Ichnology and sedimentology of a tide-influenced delta, Lower Miocene Chenque Formation, Patagonia, Argentina: trace-fossil distribution and response to environmental stresses. Palaeogeogr. Palaeoclimatol. Palaeoecol. 273, 75-86.

Cas, R.A.F., Wright, J.V., 1987. Volcanic Successions: Modern and Ancient. Unwin Hyman, London, p. 528.

Cassini, G.H., Cerdeño, E., Villfañe, A.L., Muñoz, N.A., 2012. Paleobiology of the Santacrucian native ungulates (Meridiungulata: Astrapotheria, Litopterna and Notoungulata). In: Vizcaíno, S.F., Kay, R.F., Bargo, M.S. (Eds.), Early Miocene Paleobiology in Patagonia: High-latitude Paleocommunities of the Santa Cruz Formation. Cambridge University Press, Cambridge, pp. 243-286.

Channing, A., Zamuner, A., Edwards, D., Guido, D., 2011. Equisetum thermale sp. nov. (Equisetales) from the Jurassic San Agustín hot spring deposit, Patagonia: Anatomy, paleoecology, and inferred paleoecophysiology. Am. J. Bot. 98, 680-697.

Choi, K.S., Dalrymple, R.W., Chun, S.S., Kim, S., 2004. Sedimentology of modern, inclined heterolithic stratification (IHS) in the macrotidal Han River Delta, Korea. J. Sediment. Res. 74, 677-689.

Corbella, H., 2002. El campo volcánico-tectónico de Pali Aike. In: Haller, M.J. (Ed.), Geología y Recursos Naturales de Santa Cruz. Relatorio XV Congreso Geológico Argentino, vol. I-18, pp. 285-301.

Crowford, R., Casadío, S., Feldmann, N., Griffin, M., Parras, A., Schweitzer, C., 2008. Mass mortality of fossil decapods within the Monte León Formation (early Miocene), Southern Argentina: victims of Andean Volcanism. Ann. Carnegie Mus. 77, 259-287.

Cuitiño, J.I., Scasso, R.A., 2010. Sedimentología y paleoambientes del Patagoniano y su transición a la Formación Santa Cruz al sur del Lago Argentino, Patagonia Austral. Rev. la Asoc. Geol. Argent. 66, 406-417.

Cuitiño, J.I., Scasso, R.A., 2012. High resolution isotopic ages for the early Miocene "Patagoniense" transgression in Southwest Patagonia: stratigraphic implications. J. South Am. Earth Sci. 38, 110-122.

Cuitiño, J.I., Scasso, R.A., 2013. Reworked pyroclastic beds in the early Miocene of Patagonia: reaction in response to high sediment supply during explosive volcanic events. Sediment. Geol. 289, 194-209.

Cuitiño, J.I., Scasso, R.A., 2008. Sedimentología y geometría de un cuerpo tobáceo en el tope de la Formación Centinela, sudoeste de la provincia de Santa Cruz. In: XII Reunión Argentina de Sedimentología, vol. 64.

Cuitiño, J.I., Ventura Santos, R., Scasso, R., 2013. Insights into the distribution of shallow-marine to estuarine Early Miocene oysters from Southwestern Patagonia: sedimentologic and stable isotopic constraints. Palaios 28, 583-598.

Dalrymple, R.W., Choi, K., 2007. Morphologic and facies trends through the fluvial-marine transition in tide-dominated depositional systems: a schematic framework for environmental and sequence-stratigraphic interpretation. EarthSci. Rev. 81, 135-174.

de Valais, S., Apezteguía, S., Garrido, A., 2012. Cretaceous small scavengers: feeding traces in tetrapod bones from Patagonia, Argentina. PLoS One 7, 1-8.

Droser, M.L., Bottjer, D.J., 1986. Ichnofabric of sandstones deposited in high-energy nearshore environments; measurement and utilization. Palaios 4, 598-604.

Duchaufour, P., 1987. Manual de Edafologia. Masson, S.A, Barcelona, p. 214.

Fernicola, J.C., Cuitiño, J.I., Vizcaíno, S., Bargo, M.S., Kay, R., 2014. Fossil localities of the Santa Cruz formation (early Miocene, Patagonia, Argentina) prospected by 
Carlos Ameghino in 1887 revisited and the location of the Notohippidian. J. South Am. Earth Sci. 52, 94-107.

Feruglio, E., 1949. Descripción Geológica de la Patagonia I, II, and III. Dirección General de Yacimientos Petrolíferos Fiscales. T1: 1-323; T2: 1-349; T3: 1-331, Buenos Aires.

Fisher, J., Nichols, G., Waltham, D., 2007. Unconfined flow deposits in distal sectors of fluvial distributary systems: examples from the Miocene Luna and Huesca Systems, Northern Spain. Sediment. Geol. 195, 55-73.

Fleagle, J.G., Perkins, M.E., Heizler, M.T., Nash, B., Bown, T.M., Tauber, A.A., Dozo, M.T., Tejedor, M.F., 2012. In: Vizcaíno, S.F., Kay, R.F., Bargo, M.S. (Eds.), Early Miocene Paleobiology in Patagonia: High-latitude Paleocommunities of the Santa Cruz Formation. Cambridge University Press, Cambridge, pp. 41-58.

Fleagle, J.G., Bown, T.M., Swisher III, C.C., Buckley, G.A., 1995. Age of the Pinturas and Santa Cruz Formations. In: Actas del VI Congreso Argentino de Paleontología y Bioestratigrafía, pp. 129-135.

Genise, J.F., Bown, T.M., 1994. New Miocene scarabeid and hymenopterous nests and Early Miocene (Santacrucian) paleoenvironments, Patagonian Argentina. Ichnos 3, 107-117.

Gibling, M.R., 2006. Width and thickness of fluvial channel bodies and valley fills in the geological record: a literature compilation and classification. J. Sediment, Res. 76, 731-770.

Gingras, M.K., Rasenen, M.E., Ranzi, A., 2002. The significance of bioturbated inclined heterolithic stratification in the southern part of the Miocene Solimoes Formation, Rio Acre, Amazonia Brazil. Palaios 17, 591-601.

Griffin, M., Parras, A., 2012. Oysters from the base of the Santa Cruz Formation (late Early Miocene) of Patagonia. In: Vizcaíno, S.F., Kay, R.F., Bargo, M.S. (Eds.), Early Miocene Paleobiology in Patagonia: High-latitude Paleocommunities of the Santa Cruz Formation. Cambridge University Press, Cambridge, pp. 83-90.

Gradstein, F.M., Ogg, J.G., Schmitz, M., Ogg, G., 2012. The Geologic Time Scale 2012. Elsevier, Oxford, UK, p. 1176.

Guillaume, B., Martinod, J., Espurt, N., 2009. Variations of slab dip and overriding plate tectonics during subduction: insights from analogue modeling. Tectonophysics 463, 167-174.

Guo, Z., Liu, J., Yu Chen, X., 2007. Effect of Miocene basaltic volcanism in Shanwang (Shandong Province, China) on environmental changes. Sci. China Ser. D: Earth Sci. 50, 1823-1827.

Hervé, F., Pankhurts, R.J., Fanning, C.M., Calderón, M., Yaxley, G.M., 2007. The South Patagonian batholith: 150 my of granite magmatism on a plate margin. Lithos 97, 373-394.

Husby, C.D., 2009. Ecophysiology and Biomechanics of Equisetum Giganteum in South America. Florida International University. Electronic Theses and Dissertations. Paper 200. http://digitalcommons.fiu.edu/etd/200.

Ihering, H., 1897. Os Molluscos dos terrenos terciarios da Patagonia. Rev. do Mus. Paul. 2, 217-382.

Johnson, S.M., Dashtgard, S.E., 2014. Inclined heterolithic stratification in a mixed tidal-fluvial channel: differentiating tidal versus fluvial controls on sedimentation. Sediment. Geol. 301, 41-53.

Kay, R.F., Perry, J., Malinzak, M., Allen, K., Kirk, E.C., Plavcan, J.M., Fleagle, J.G., 2012a. Paleobiology of Santacrucian primates. In: Vizcaíno, S.F., Kay, R.F., Bargo, M.S. (Eds.), Early Miocene Paleobiology in Patagonia: High-latitude Paleocommunities of the Santa Cruz Formation. Cambridge University Press, Cambridge, pp. 306-330.

Kay, R.F., Vizcaíno, S.F., Bargo, M.S., 2012b. A review of paleoenvironments and paleoecology of the Miocene Santa Cruz Formation. In: Vizcaíno, S.F., Kay, R.F., Bargo, M.S. (Eds.), Early Miocene Paleobiology in Patagonia: High-latitude Paleocommunities of the Santa Cruz Formation. Cambridge University Press, Cambridge, pp. 331-365.

Kay, R.F., Vizcaino, S.F., Bargo, M.S., Perry, J.M.G., Prevosti, F.J., Fernicola, J.C., 2008. Two new fossil vertebrate localities in the Santa Cruz Formation (late Early-early Middle Miocene, Argentina), 51 South latitude. J. South Am. Earth Sci. 25, 187-195.

Kirby, M.X., 2001. Differences in growth rate and environment between Tertiary and Quaternary Crassostrea oysters. Paleobiology 27, 84-103.

Kraus, M.J., Hasiotis, S.T., 2006. Significance of different modes of rhizolith preservation to interpreting paleoenvironmental and paleohydrologic settings: examples from paleogene paleosols, Bighorn Basin, Wyoming, U.S.A. J. Sediment. Res. 76, 633-646.

Kraus, M.J., Aslan, A., 1993. Eocene hydromorphic paleosols: significance for interpreting ancient floodplain processes. J. Sediment. Petrol. 63, 453-463.

Krapovickas, V., 2012. Ichnology of distal overbank deposits of the Santa Cruz Formation (late Early Miocene): paleohydrologic and paleoclimatic significance. In: Vizcaíno, S.F., Kay, R.F., Bargo, M.S. (Eds.), Early Miocene Paleobiology in Patagonia: High-latitude Paleocommunities of the Santa Cruz Formation. Cambridge University Press, Cambridge, pp. 91-103.

Krapovickas, V., Bargo, M.S., Vizcaíno, S.F., Raigemborn, M.S., Fernícola, J.C., 2013. Huellas fósiles de mamíferos de la Formación Santa Cruz (Mioceno Inferior; provincia de Santa Cruz): aspectos tafonómicos. In: XXVII Jornadas Argentina de Paleontología de Vertebrados, vol. 55.

Lara, L.E., 2009. The 2008 eruption of the Chaitén Volcano, Chile: a preliminary report. Andean Geol. 36, 125-129.

Longhitano, S.G., Mellere, D., Steel, R.J., Ainsworth, R.B., 2012. Tidal depositional systems in the rock record: a review and new insights. Sediment. Geol. 279, 2-22.

MacEachern, J.A., Gingras, M.A., 2007. Recognition of brackish-water trace-fossil suites in the Cretaceous Western interior seaway of Alberta, Canada. SEPM Spec. Publ. 88, 149-193.
Mackay, D.A., Dalrymple, R.W., 2011. Dynamic mud deposition in a tidal environemnet: the record of fluid-mud deposition in the Cretaceous Bluesky Formation, Alberta, Canada. J. Sediment. Res. 2011, 901-920.

Malumián, N., 1999. La sedimentación y el volcanismo terciarios en la Patagonia Extraandina, 1. La sedimentación en la Patagonia Extraandina. In: Caminos, J. (Ed.), Geología Argentina. Anales del Instituto de Geología y Recursos Minerales, vol. 29, pp. 557-578.

Marshall, L.G., 1976. Fossil localities for santacrucian (Early Miocene) mammals from Santa Cruz province, southern patagonia, Argentina. J. Paleontol. 50, 1129-1142.

Marshall, L.G., Drake, R.E., Curtis, G.H., Butler, R., Flanagan, K., Naeser, C., 1986. Geochronology of type Santacrucian (middle Tertiary) land mammal age, Patagonia, Argentina. J. Geol. 94, 449-457.

Matheos, S.D., Raigemborn, M.S., Vizcaíno, S.F., Bargo, M.S., Vizcaíno, J., 2008. Sedimentología de la transición marino-continental del Mioceno temprano en el Parque Nacional Monte León. XVII Congreso Geológico Argentino, Tomo II, Santa Cruz, Argentina, pp. 876-877.

Matheos, S.D., Raigemborn, M.S., Gomez Peral, L., Tauber, A.A., 2010. Paleoclimatic interpretation from clay minerals in the early-middle Miocene of Southeast Patagonia, Argentina. In: 18th International Sedimentological Congress, Proceedings, 247.

Matheos, S.D., Raigemborm, M.S., 2012. Sedimentology and paleoenvironment of the Santa Cruz Formation. In: Vizcaíno, S.F., Kay, R.F., Bargo, M.S. (Eds.), Early Miocene Paleobiology in Patagonia: High-latitude Paleocommunities of the Santa Cruz Formation. Cambridge University Press, Cambridge, pp. 59-82.

Martinic, M., 2008. Registro histórico de antecedentes volcánicos y sísmicos en la Patagonia Austral y Tierra del Fuego. Magallania 36, 5-18.

Menichetti, M., Lodolo, E., Tassone, A., 2008. Structural geology of the Fuegian Andes and Magallanes fold-and-thrust belt - Tierra del Fuego Island. Geol. Acta 6, 19-42.

Miall, A., 1996. The Geology of Fluvial Deposits: Sedimentary Facies, Basin Analysis and Petroleum Geology. Springer-Verlarg, Berlin, p. 582.

Miller, K.G., Kominz, M.A., Browning, J.V., Wright, J.D., Mountain, G.S., Katz, M.E., Sugarman, P.J., Cramer, B.S., Christie-Blick, N., Pekar, S.F., 2005. The phanerozoic record of global sea-level change. Science 310, 1293-1298.

Mulena, C., Allende, D., Puliafito, E., Lakkis, G., 2012. Estudio de la dispersión de cenizas volcánicas del Puyehue: simulaciones y Validación. Av. Energías Renov. Medio Ambiente 16, 7-14.

Nichols, G.J., Fisher, J.A., 2007. Processes, facies and architecture of fluvial deposits. Sediment. Geol. 195, 75-90.

Olivero, E.B., Malumián, N., 2002. Upper Cretaceous-Cenozoic clastic wedges from the Austral-Malvinas foreland basins, Tierra del Fuego, Argentina: Eustatic and tectonic controls. In: 3rd European Meeting on the Palaeontology and Stratigraphy of Latin America, Toulouse, France, Addendum, pp. 6-9.

Olivero, E.B., Malumián, N., 2008. Mesozoic-cenozoic stratigraphy of the Fuegian Andes, Argentina. Geol. Acta 6, 5-18.

Orton, G., 1996. Volcanic environments. In: Reading, H. (Ed.), Sedimentary Environments, Processes, Facies and Stratigraphy. Blackwell, New York, pp. 485-567.

Page, C.N., 1972. An assessment of inter-specific relationships in Equisetum subgenus Equisetum. New. Phytol. 71, 355-369.

Palazzesi, L., Barreda, V.D., Cuitiño, J.I., Guler, M.V., Tellería, M.C., Ventura Santos, R., 2014. Fossil pollen records indicate that Patagonian desertification was not solely a consequence of Andean uplift. Nat. Commun. 5 (3558), 1-8.

Parras, A., Dix, G.R., Griffin, M., 2012. Sr-isotope chronostratigraphy of PaleogeneeNeogene marine deposits: austral Basin, southern Patagonia (Argentina). J. South Am. Earth Sci. 37, 122-135.

Parras, A., Griffin, M., Feldmann, R., Casadío, S., Schweitzer, C., Marenssi, S., 2008. Correlation of marine beds based on $\mathrm{Sr}$ - and Ar-date determinations and faunal affinities across the Paleogene/Neogene boundary in southern Patagonia, Argentina. J. South Am. Earth Sci. 26, 204-216.

Parras, A., Griffin, M., 2009. Darwin's Great Patagonian Formation at the mouth of the Santa Cruz River: a reppraisal. Rev. la Asoc. Geol. Argent. 64, 70-82.

Pascual, R., Ortega Hinojosa, E.J., Gondar, D., Tonni, E.P., 1965. Las Edades del Cenozoico mamalífero de la Argentina, con especial atención a aquellas del territorio bonaerense. An. Com. Investig. Científicas Prov. Buenos Aires 6, 165-193.

Patterson, B., Pascual, R., 1972. The fossil mammal fauna of south america. In evolution, mammals, and southern continents. In: Keast, A., Erk, F.C., Glass, B. (Eds.), Evolution, Mammals and Southern Continents. State University of New York Press, New York, pp. 274-309.

Pearson, N.J., Mángano, M.G., Buatois, L.A., Casadío, S., Rodriguez Raising, M., 2012. Ichnology, sedimentology, and sequence stratigraphy of outer-estuarine and coastal-plain deposits: Implications for the distinction between allogenic and autogenic expressions of the Glossifungites Ichnofacies. Palaeogeography, Palaeoclimatology, Palaeoecology 333, 192-217.

Perkins, M.E., Fleagle, J.G., Heizler, M.T., Nash, B., Bown, T.M., Tauber, A.A., Dozo, M.T., 2012. In: Vizcaíno, S.F., Kay, R.F., Bargo, M.S. (Eds.), Early Miocene Paleobiology in Patagonia: High-latitude Paleocommunities of the Santa Cruz Formation. Cambridge University Press, Cambridge, pp. 23-40.

Peroni, G., Cagnolatti, M., Pedrazzini, M., 2002. Cuenca Austral: marco geológico y reserve histórica de la actividad petrolera. In: Schiuma, M., Hinterwimmer, G., Vergani, G. (Eds.), Rocas reservorio de las cuencas productivas de la Argentina. V Congreso de Exploración y Desarrollo de Hidrocarburos, pp. 11-26.

Piccolo, M.C., Perillo, G.M.E., 1999. The Argentina estuaries: a review. In: Perillo, G.M.E., Piccolo, M.C., Pino-Quivira, M. (Eds.), Estuaries of South America; Their Geomorphology and Dynamics. Springer-Verlag, New York, pp. 101-132. 
PiPujol, M.D., Buurman, P., 1994. The distinction between ground-water gley and surface-water gley phenomena in Tertiary paleosols of the Ebro Basin, NE Spain. Palaeogeogr. Palaeoclimatol. Palaeoecol. 110, 103-113.

Plink-Bjorklund, P., 2005. Stacked fluvial tide-dominated estuarine deposits in highfrequency (fourth-order) sequences of the Eocene Central Basin, Spitsbergen. Sedimentology 52, 391-428.

Ratcliffe, B.C., Fagerstrom, J.A., 1980. Invertebrate lebensspuren of Holocene floodplains: their morphology, origin and palaeoecological significance. J. Paleontol. 54, 614-630.

Raigemborn, M.S., Krapovickas, V., Matheos, S.D., Vizcaíno, S.F., Bargo, M.S. Zapata, L., 2012. Condiciones paleoambientales de facies edafizadas de la Formación Santa Cruz, Neógeno temprano de Patagonia Austral, Argentina. In: XII Reunión Argentina de Sedimentología, Actas, pp. 181-182.

Ramos, V.A., Ghiglione, M.C., 2008. Tectonic evolution of the patagonian Andes. In: Rabassa, J. (Ed.), The Late Cenozoic of Patagonia and Tierra Del Fuego, vol. 11. Developments in Quaternary Sciences, pp. 57-72.

Ramos, V.A., Kay, S.M., 1992. The Southern Patagonian plateau basalts: retroarc testimony of a ridge collision, Argentina. Tectonophysics 205, 261-282.

Retallack, G., 2001. Soils of the Past. An Introduction to Paleopedology, second ed. Blackwell Science Ltd., London, p. 404.

Riggs, E.S., 1928. Work accomplished by the field museum paleontological expeditions to SouthAmerica. Sci. New Ser. 67, 585-587.

Rogers, R.R., Kidwell, S.M., 2000. Associations of vertebrate skeletal concentrations and discontinuity surfaces in terrestrial and shallow marine records: a test in the Cretaceous of Montana. J. Geol. 108, 131-154.

Rossello, E.A., Haring, C.E., Cardinali, G., Suarez, F., Laffitte, G.A., Nevestic, A.V., 2008. Hydrocarbons and petroleum geology of Tierra del Fuego, Argentina. Geol. Acta 6 , 69-83.

Rossetti, D.F., 2000. Influence of low amplitude/high frequency relative sea-leve changes in a wave-dominated estuary (Miocene), Sao Luis Basin, northern Brazil. Sediment. Geol. 133, 295-324.

Russo, A., Flores, M., Di Benedetto, H., 1980. Patagonia austral extraandina. In: Geología Regional Argentina, En. Segundo Simposio Geología Regiona Argentina, vol. 2. Academia Nacional de Ciencias, pp. 1431-1462.

Sacomani, L., Panza, J.L., 2012. Hoja Geológica 5169-I y 5169-II, Puerto Coig y Puerto Santa Cruz. Instituto de Geología y Recursos Minerales, Servicio Geológico Minero Argentino. Boletín 393, 133.

Santos, A.E., Rosetti, D.F., 2006. Depositional model of the Ipixuna Formation (Late Creatceous-?Early Tertiary), Rio Capim area, Northern Brazil. Lat. Am. J. Sedimentol. Basin Analysis 13, 101-117.

Scasso, R. Corbella, H., Tiberi, P., 1994. Sedimentological analysis of the tephra from the 12-15 August 1991 eruption of Hudson volcano. Bull. Volcanol. 56, 121-132.

Scasso, R., del Río, C.J., 1987. Ambientes de sedimentación y proveniencia de la secuencia marina del Terciario Superior de la región de Península Valdés. Rev. la Asoc. Geol. Argent. 42, 291-321.

Scasso, R.A., Dozo, M.T., Cuitiño, J.I., Bouza, P., 2012. Meandering tidal-fluvial channels and lag concentration of terrestrial vertebrates in the fluvialtida transition of an ancient estuary in Patagonia. Lat. Am. J. Sedimentol. Basin Analysis 19, 27-45.

Seilacher, A., 1964. Biogenic sedimentary structures. In: Imbrie, J., Newell, N. (Eds.), Approaches to Paleoecology. John Wiley and Sons, New York, pp. 296-316.

Sisulack, C.F., Dashtgard, S.E., 2012. Seasonal control son the development and carácter of inclined heterolithic stratification in a tide-influence, fluvially dominated cannel: Fraser River, Canadá. J. Sediment. Res. 82, 244-257.

Smith, D.G. Hubbard, S.M., Leckie, D.A., Fustic, M., 2009. Counter point bar deposits: lithofacies and reservoir significance in the meandering modern Peace River and ancient McMurray Formation, Alberta, Canada. Sedimentology 56 $1655-1669$.
Smith, G.A., 1987. Sedimentology of volcanism-induced aggradation in fluvial basins: examples from the Pacific Northwest, USA. In: Ethridge, F.G., Flores, R.M. Harvey, M.G. (Eds.), Recent Developments in Fluvial Sedimentology. Society of Economic Paleontologists and Mineralogists Special Publication, vol. 39. American Association of Petroleum Geologists, pp. 217-228.

Smith, G.A., 1991. Facies equences and geometries in continental volcaniclastic sediments. In: Fisher, R.V., Smith, G.A. (Eds.), Sedimentation in Volcanic Settings. Society for Sedimentary Geology Special Publication. Society for Sedimentary Geology, Tulsa, pp. 109-121.

Stern, C., 1991. Mid-Holocene tephra on Tierra del Fuego ( $\left.54^{\circ} \mathrm{S}\right)$ derived from the Hudson Volcano ( $\left.46^{\circ} \mathrm{S}\right)$ : evidence for a large explosive eruption. Rev. Geol. Chile 18, 139-146.

Tauber, A.A. 1994. Estratigrafía y vertebrados fósiles de la Formación Santa Cruz (Mioceno Inferior) en la costa atlántica entre las rías del Coyle y Río Gallegos, Provincia de Santa Cruz, República Argentina. Universidad Nacional de Córdoba, Argentina. Unpublished Ph.D thesis.

Tauber, A.A., 1997a. Bioestratigrafía de la Formación Santa Cruz (Mioceno inferior) en el extremo sudeste de la Patagonia. Ameghiniana 34, 413-426.

Tauber, A.A., 1997b. Paleoecología de la Formación Santa Cruz (Mioceno inferior) en el extremo sudeste de la Patagonia. Ameghiniana 34, 517-529.

Tunbridge, I.P., 1981. Sandy high-energy flood sedimentation: some criteria for recognition, with an example from the Devonian of SW Engalnd. Sediment. Geol. 28, 79-95.

Umazano, A.M., Bellosi, E.S., Visconti, G., Melchor, R.N., 2012. Detecting allocyclic signals in volcaniclastic fluvial successions: facies, architecture and stacking pattern from the Cretaceous of central Patagonia, Argentina. J. South Am. Earth Sci. 40, 94-115.

Van den Berg, J.H., Boersma, J.R., van Gelder, A., 2007. Diagnostic sedimentary structures of the fluvial-tidal transition zone-Evidence from deposits of the Rhine and Meuse. Neth. J. Geosci. 86, 287-306.

Vilas, F., Bernabéu, A., Rubio, B., Rey, D., 2010. Estuarios, rías y llanuras intermareales. In: Arche, A. (Ed.), Sedimentología: del proceso físico a la Cuenca sedimentaria. Consejo Superior de investigaciones Científicas, Madrid, pp. 619-674.

Vizcaíno, S.F., Bargo, M.S., Kay, R.F., Fariña, R.A., Giacomo, M.D., Perry, J.M., Prevosti, F.J., Toledo, N., Cassini, G.H., Fernicola, J.C., 2010. A baseline paleoecological study for the Santa Cruz Formation (late-Early Miocene) at the Atlantic coast of Patagonia, Argentina. Palaeogeogr. Palaeoclimatol. Palaeoecol. 292, 507-519.

Vizcaíno, S.F., Kay, R.F., Bargo, M.S., 2012a. Early Miocene Paleobiology in Patagonia: High-latitude Paleocommunities of the Santa Cruz Formation. Cambridge University Press, Cambridge, p. 370.

Vizcaíno, S.F., Kay, R.F., Bargo, M.S., 2012b. Background for a paleoecological study of the Santa Cruz Formation (late Early Miocene) on the Atlantic Coast of Patagonia. In: Vizcaíno, S.F., Kay, R.F., Bargo, M.S. (Eds.), Early Miocene Paleobiology in Patagonia: High-latitude Paleocommunities of the Santa Cruz Formation. Cambridge University Press, Cambridge, pp. 1-22.

Vizcaíno, S.F. Fernicola, J.C. Bargo, M.S., 2012c. Paleobiology of Santacrucian glyptodons and armadillos (Xenarthra, Cingulata). In: Vizcaíno, S.F., Kay, R.F., Bargo, M.S. (Eds.), Early Miocene Paleobiology in Patagonia: High-latitude Paleocommunities of the Santa Cruz Formation. Cambridge University Press, Cambridge, pp. 194-209.

Zachos, J.C., Dickens, G.R., Zeebe, R.E., 2008. An early Cenozoic perspective on greenhouse warming and carbon-cycle dynamics. Nature 45, 279-283.

Zapata, L., Krapovickas, V., Raigemborn, M.S., Matheos, S., 2013. Presencia de icnofacies de Glossifungites en la base de la Formación Santa Cruz (Mioceno inferior-medio), sudeste de la provincia de Santa Cruz, Patagonia Austral. Simp. Latinoam. Icnol. 73. 